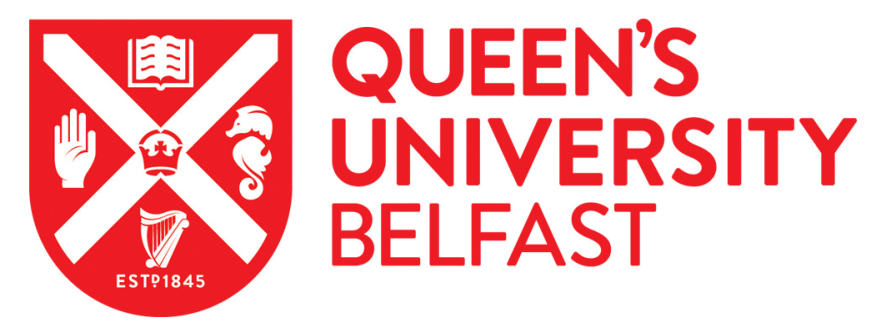

\title{
Effect of web holes on web crippling strength of cold-formed steel channel sections under end-one-flange loading condition - Part II: Parametric study and proposed design equations
}

Lian, Y., Uzzaman, A., Lim, J. B. P., Abdelal, G., Nash, D., \& Young, B. (2016). Effect of web holes on web crippling strength of cold-formed steel channel sections under end-one-flange loading condition - Part II: Parametric study and proposed design equations. Thin-Walled Structures, 107, 489-501. https://doi.org/10.1016/j.tws.2016.06.026

\section{Published in:}

Thin-Walled Structures

Document Version:

Peer reviewed version

Queen's University Belfast - Research Portal:

Link to publication record in Queen's University Belfast Research Portal

\section{Publisher rights}

(c) 2016 Elsevier Ltd. This manuscript version is made available under the CC-BY-NC-ND 4.0 license http://creativecommons.org/licenses/by$\mathrm{nc}-\mathrm{nd} / 4.0 /$ which permits distribution and reproduction for non-commercial purposes, provided the author and source are cited.

\section{General rights}

Copyright for the publications made accessible via the Queen's University Belfast Research Portal is retained by the author(s) and / or other copyright owners and it is a condition of accessing these publications that users recognise and abide by the legal requirements associated with these rights.

Take down policy

The Research Portal is Queen's institutional repository that provides access to Queen's research output. Every effort has been made to ensure that content in the Research Portal does not infringe any person's rights, or applicable UK laws. If you discover content in the

Research Portal that you believe breaches copyright or violates any law, please contact openaccess@qub.ac.uk. 


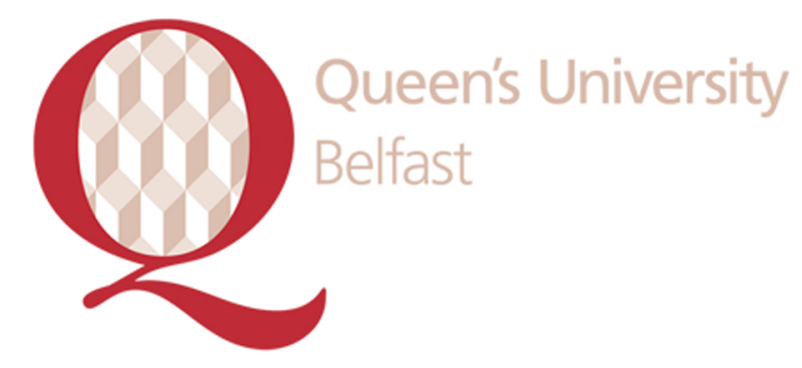

\title{
EFFECT OF WEB HOLES ON WEB CRIPPLING STRENGTH OF COLD-FORMED STEEL CHANNEL SECTIONS UNDER END-ONE- FLANGE LOADING CONDITION - PART II: PARAMETRIC STUDY AND PROPOSED DESIGN EQUATIONS
}

\author{
Lian, Y., uzzaman, A., Lim, J. B. P., Abdelal, G., Sha, W., Nash, D., \& Young, B. (2016). EFFECTT OF WEB \\ HOLES ON WEB CRIPPLING STRENGTH OF COLD-FORMED STEEL CHANNEL SECTIONS UNDER END- \\ ONE-FLANGE LOADING CONDITION - PART II: PARAMETRIC STUDY AND PROPOSED DESIGN \\ EQUATIONS.
}

Document Version:

Early version, also known as pre-print

Queen's University Belfast - Research Portal:

Link to publication record in Queen's University Belfast Research Portal

General rights

Copyright for the publications made accessible via the Queen's University Belfast Research Portal is retained by the author(s) and / or other copyright owners and it is a condition of accessing these publications that users recognise and abide by the legal requirements associated with these rights.

\section{Take down policy}

The Research Portal is Queen's institutional repository that provides access to Queen's research output. Every effort has been made to ensure that content in the Research Portal does not infringe any person's rights, or applicable UK laws. If you discover content in the Research Portal that you believe breaches copyright or violates any law, please contact openaccess@qub.ac.uk. 


\title{
EFFECT OF WEB HOLES ON WEB CRIPPLING STRENGTH OF \\ COLD-FORMED STEEL CHANNEL SECTIONS UNDER END- \\ ONE-FLANGE LOADING CONDITION - PART II: PARAMETRIC STUDY AND PROPOSED DESIGN EQUATIONS
}

\author{
Ying Lian ${ }^{\mathrm{a}}$, Asraf Uzzaman ${ }^{\mathrm{b}}$, James B.P Limª,c, Gasser Abdelal ${ }^{\mathrm{d}}$, Wei Sha ${ }^{\mathrm{a}}$, \\ David Nash ${ }^{\mathrm{b}}$, Ben Young ${ }^{\mathrm{e}}$
}

a SPACE, David Keir Building, Queen's University, Belfast, BT9 5AG, UK

b Department of Mechanical and Aerospace Engineering, The University of Strathclyde, 75 Montrose Street, Glasgow G1 1XJ, UK

c Civil \& Environmental Engineering, The University of Auckland, 20 Symonds Street, Auckland, New Zealand

d Department of Mechanical and Aerospace Engineering, Queen's University, Belfast, BT9 5AH, UK

e Department of Civil Engineering, The University of Hong Kong, Pokfulam Road, Hong Kong

\begin{abstract}
A parametric study of cold-formed steel sections with web openings subjected to web crippling under end-one-flange (EOF) loading condition is undertaken, using finite element analysis, to investigate the effects of web holes and cross-section sizes. The holes are located either centred above the bearing plates or with a horizontal clear distance to the near edge of the bearing plates. It was demonstrated that the main factors influencing the web crippling strength are the ratio of the hole depth to the depth of the web, the ratio of the length of bearing plates to the flat depth of the web and the location of the holes as defined by the distance of the hole from the edge of the bearing plate divided by the flat depth of web. In this study, design recommendations in the form of web crippling strength reduction factor equations are proposed, which are conservative when compared with the experimental and finite element results.
\end{abstract}

\section{Keywords}

Cold-formed steel; Web crippling; Finite element analysis; Web hole; Channel section; Reduction factor; Design recommendations 


\section{Nomenclature}

A Web holes ratio;

a Diameter of circular web holes;

$b_{f} \quad$ Overall flange width of section;

$b_{l} \quad$ Overall lip width of section;

COV Coefficient of variation;

$d \quad$ Overall web depth of section;

$d_{\text {hole }} \quad$ Clear distance between holes;

$d_{e d} \quad$ Distance between end of member and edge of hole;

DL Dead load;

E Young's modulus of elasticity;

FEA Finite element analysis;

$F_{m} \quad$ Mean value of fabrication factor;

$f_{\mathrm{y}} \quad$ Material yield strength;

$h \quad$ Depth of flat portion of web;

L Length of specimen;

LL Live load;

$M_{m} \quad$ Mean value of material factor;

$N \quad$ Length of bearing plate;

$P \quad$ Experimental and finite element ultimate web crippling load per web;

$P_{\mathrm{BS}} \quad$ Nominal web crippling strength obtained from British Standard;

$P_{\text {Euro }} \quad$ Nominal web crippling strength obtained from European Code;

$P_{\text {EXP }} \quad$ Experimental ultimate web crippling load per web;

$P_{\text {FEA }} \quad$ Web crippling strength per web predicted from finite element (FEA); 


\begin{tabular}{|ll|}
\hline$P_{\mathrm{NAS}}$ & Nominal web crippling strength obtained from North American Specification; \\
$P_{m}$ & Reduction factor; \\
$R_{\mathrm{P}}$ & Proposed reduction factor; \\
$r_{\mathrm{i}}$ & Inside corner radius of section; \\
$t$ & Thickness of section; \\
$V_{F}$ & Coefficient of variation of fabrication factor; \\
$V_{M}$ & Coefficient of variation of material factor; \\
$V_{P}$ & Coefficient of variation of tested-to-predicted load ratio; \\
$x$ & Horizontal clear distance of web holes to near edge of bearing plate; \\
$\mathrm{X}$ & Web holes distance ratio; \\
$\theta$ & Angle between web and bearing surface; \\
$\beta$ & Reliability index;
\end{tabular}




\section{Introduction}

Strength reduction factor equations have recently been proposed by Uzzaman et al. [1-4] for web crippling strength of cold-formed steel channel -sections with circular holes in the web under the end-two-flange (ETF) and interior-two-flange (ITF) loading conditions. This paper extends the work of Uzzaman et al. [1-4] to consider the endone-flange (EOF) loading condition for cold-formed steel channel -sections with circular holes in the web.

For this EOF loading condition, experimental and numerical investigations have been discussed in the companion paper [5]. In this study, non-linear finite element analysis (FEA) is used to conduct parametric studies to investigate the effect of circular holes; as shown in Fig. 1, these holes are either located centred above the bearing plates or having a horizontal clear distance to the near edge of the bearing plates. The cases of both flanges unfastened and fastened to the bearing plates are considered.

In the literature, for the EOF loading condition, LaBoube et al. [6] have previously considered the case of a circular hole having a horizontal clear distance to the near edge of the bearing plates, but only for the case where the flanges are fastened to the bearing plates. The strength reduction factor equation proposed by LaBoube et al. [6] was subsequently adopted by the North American Specification (NAS) [7] for coldformed steel sections. This strength reduction factor equation, however, was limited to thicknesses ranging from $0.83 \mathrm{~mm}$ to $1.42 \mathrm{~mm}$. Other similar work described in the literature include that of $\mathrm{Yu}$ and Davis [8] who studied the case of both circular and square web openings located and centred beneath the bearing plates under interior-oneflange loading condition, Sivakumaran and Zielonka [9] who considered the case of rectangular web openings located and centred beneath the bearing plates under the interior-one-flange loading condition, and Zhou and Young [10] who proposed strength 
reduction factor equations for aluminium alloy square sections with circular web openings located and centred beneath the bearing plates under end-two-flange and interior-two-flange loading conditions. Recent research on web crippling of cold-formed steel channel -sections, other than that by Uzzaman et al. who again considered only the two-flange loading conditions, has not covered the case of holes [11-14].

In this study, the general purpose finite element program ABAQUS [15] was used for the numerical investigation. Based on the test data found in the companion paper [5], both for the case of channel -sections without holes and with holes, and the numerical results obtained from this study, an extensive statistical analysis was performed. For channel -sections with circular web holes, design recommendations in the form of web crippling strength reduction factor equations are proposed, which are conservative when compared with the experimental and finite element results.

\section{Experiment investigation}

Lian et al. [5] presented a test programme on cold-formed steel channel sections with circular web holes subjected to web crippling, as shown in Fig. 2. As can be seen, each test comprised a pair of channel sections with a load transfer block bolted between them. Washer plates of thickness $6 \mathrm{~mm}$ were bolted to the outside of the webs of the channel -sections. The size of the web holes was varied in order to investigate the effect of the web holes on the web crippling strength. Circular holes with nominal diameters (a) ranging from $55 \mathrm{~mm}$ to $179 \mathrm{~mm}$ were considered in the experimental investigation. The ratio of the diameter of the holes to the depth of the flat portion of the webs $(a / h)$ was $0.2,0.4$ and 0.6. All test specimens were fabricated with web holes located at the mid-depth of the webs and centred above the bearing plates or with a horizontal clear distance to the near edge of the bearing plates (x), as shown in Fig. 1. The test data 
reported in the companion paper [5] are used in this paper for the development of web crippling strength reduction equations.

\section{Numerical investigation}

The non-linear general purpose finite element program ABAQUS [15] was used to simulate the web crippling behaviour of the channel sections with and without holes. The bearing plates, the load transfer block, the channel sections with circular holes and the contact interfaces between the bearing plates and the channel section and load transfer block were modelled. The details of the FEM are described in the companion paper [5]. In the finite element model, the measured cross-section dimensions and the material properties obtained from the tests were used. The channel sections of the model were based on the centreline dimensions of the cross-sections. ABAQUS [15] required the material stress-strain curve input as true stress-true curve. The stress-strain curves were directly obtained from the tensile tests and converted into true stress-strain curves as specified in the ABAQUS manual [15]. Finite element mesh sizes were $5 \mathrm{~mm} \times 5$ $\mathrm{mm}$ for the cold-formed steel channel sections and $8 \mathrm{~mm} \times 8 \mathrm{~mm}$ for the bearing plates and load transfer blocks.

The channel section specimens were tested in pairs, which were bolted to a load transfer block at the central loading point through the web by vertical row of M16 high tensile bolts. In the shell element idealisation, cartesian connectors with an in-plane stiffness were used to simulate bolt-hole elongation instead of physically modelling bolts and holes. "CONN3D2" connector elements were used to model the in-plane translational stiffness i.e. $y$ - and $z$-directions. The in-plane stiffness of the connector element was $10 \mathrm{kN} / \mathrm{mm}$, which Lim et al. [18-19] suggestion would be suitable. In the $\mathrm{x}$-direction, the nodes were prevented from translating. 


\section{Parametric study}

The finite element model developed closely predicted the behaviour of the channel sections with circular web holes subjected to web crippling. Using these models, parametric studies were carried out to study the effects of web holes and crosssection sizes on the web crippling strengths of channel sections subjected to web crippling. The cases of both flanges fastened and flanges unfastened to the bearing plates were considered.

The web crippling strength predicted was influenced primarily by the ratio of the hole depth to the flat portion of the web, the ratio of the bearing length to the flat portion of the web and the location of the hole as defined by the distance of the hole from the edge of the bearing divided by the flat portion of the web. In order to find the effect of $a / h, N / h$ and $x / h$ on the web crippling strength of channel sections with web holes, parametric studies were carried out considering the web holes, different bearing plate lengths, the cross-section sizes and location of the holes.

The specimens consisted of three different section sizes, having thicknesses $(t)$ ranging from $1.23 \mathrm{~mm}$ to $6.0 \mathrm{~mm}$ and web slenderness $(h / t)$ values ranging from 111.7 to 157.8. The ratios of the diameter of the holes $(a)$ to the depth of the flat portion of the webs $(h)$ were $0.2,0.4,0.6$ and 0.8 . The ratios of the distance of the holes $(x)$ to the depth of the flat portion of the web $(h)$ were $0.2,0.4$ and 0.6. Bearing plates of lengths $(N)$ equal to $100 \mathrm{~mm}, 120 \mathrm{~mm}$ and $150 \mathrm{~mm}$ are considered. For each series of specimens, the web crippling strengths of the sections without the web holes were obtained. Thus, the ratio of the web crippling strengths for sections with web holes divided by the sections without web holes, which is the strength reduction factor $(R)$, was used to quantify the degrading influence of the web holes on the web crippling strengths. The material properties obtained from the coupon tests are presented in the companion paper [5] were used in the finite element models in the parametric study. In 
Tables 1 to 6 , the specimens were labelled such that the nominal dimension of the specimen and the length of the bearing as well as the ratio of the diameter of the holes to the depth of the flat portion of the webs $(a / h)$ could be identified from the label. Details of the specimens labelling are described in the companion paper [5].

For the centred hole, a total of 182 specimens was analysed in the parametric study investigating the effect of the ratios of $a / h$ and $N / h$. The cross-section dimensions as well as the web crippling strengths $\left(P_{\mathrm{FEA}}\right)$ per web predicted from the FEA are summarised in Table 1 and Table 2.

The effect of the ratios of $a / h$ and $N / h$ on the reduction factor of the web crippling strength is shown in Fig. 3 and Fig. 4 for the C142 specimen. From Fig. 3(a), as can be expected, as the parameter $a / h$ increases the reduction in strength also increases (or the strength reduction factor decreases); also, as expected, the reduction in strength of the 6 mm thick sections is smallest and that the reduction in strength increases as the section becomes thinner. From Fig. 3(b), it can be seen that the reduction in strength for the fastened case is less than the flanges unfastened case.

From Fig. 4(a), it can be seen that the reduction in strength is not sensitive to the ratio $N / h$. Again, the $6 \mathrm{~mm}$ thick sections have the smallest reduction in strength (or the highest strength reduction factor); also, as the parameter $a / h$ increases the reduction in strength decreases. From Fig. 4(b), it can be seen that the reduction in strength is more sensitive to the $N / h$ ratio for the flanges fastened case; for the $1.3 \mathrm{~mm}$ thick section the reduction in strength decreases as the ratio $N / h$ increases.

For the offset hole, a total of 456 specimens was analysed in the parametric study investigating the effect of $a / h$ and $x / h$. The cross-section dimensions as well as the web crippling strengths $\left(P_{\mathrm{FEA}}\right)$ per web predicted from the FEA are summarised in Tables 3 to 6 . 
The effect of the ratios of $a / h$ and $x / h$ on the reduction factor of the web crippling strength is shown in Fig. 5 and Fig. 6 for the C142 specimen. From Fig. 5(a), as can be expected, as the parameter $a / h$ increases the reduction in strength also increases (or the strength reduction factor decreases); however, this reduction in strength is small. From Fig. 5(b), it can be seen that the reduction in strength is almost the same for the flanges fastened case.

From Fig. 6(a), it can be seen that the reduction in strength is not sensitive to the ratio $x / h$. The reduction in strength can be seen to be more sensitive to the ratios of $a / h$. From Fig. 6(b), it can be seen that the reduction in strength is less for the flanges fastened case.

\section{Reliability analysis}

The reliability of the cold-formed steel section design rules is evaluated using reliability analysis. The reliability index $(\beta)$ is a relative measure of the safety of the design. A target reliability index of 2.5 for cold-formed steel structural members is recommended as a lower limit in the NAS [7]. The design rules are considered to be reliable if the reliability index is greater than or equal to 2.5. The load combination of 1.2DL + 1.6LL as specified in the American Society of Civil Engineers Standard [20] was used in the reliability analysis, where DL is the dead load and LL is the live load. The statistical parameters are obtained from Table F1 of the NAS [7] for compression members, where $M_{m}=1.10, F_{m}=1.00, V_{M}=0.10$, and $V_{F}=0.05$, which are the mean values and coefficients of variation for material properties and fabrication factors.

The statistical parameters $P_{m}$ and $V_{P}$ are the mean value and coefficient of variation of load ratio are shown in Tables 10 to 13 , respectively. In calculating the reliability index, the correction factor in the NAS was used. Reliability analysis is detailed in the NAS [7]. In the reliability analysis, a constant resistance factor $(\phi)$ of 
0.85 was used. It is shown that the reliability index $(\beta)$ is greater than the target value of 2.5 as shown in Tables 10 to 13 .

\section{Comparison of experimental and numerical results with current design}

\section{strengths for cold-formed steel sections without web holes}

As mentioned earlier, the current cold-formed design standards $[7,16,17]$ do not provide design recommendations for cold-formed steel sections with web holes subjected to web crippling under EOF loading conditions, where the hole is located centred above the bearing plate. However, the web crippling strengths for sections without holes, from tests and FEA results, can be compared with the web crippling strengths obtained from design codes.

According to Beshara and Schuster [21], NAS [7] design expressions have limitations in the parameters. The design equation for the case of flanges fastened to the supports, is limited to specimen thicknesses ranging from $1.16 \mathrm{~mm}$ to $1.45 \mathrm{~mm}$ and $0.2 \%$ proof stress (yield stresses) ranging from $323 \mathrm{MPa}$ to $448 \mathrm{MPa}$. The design equation for the case of flanges unfastened to the supports, is limited to specimen thicknesses ranging from $1.194 \mathrm{~mm}$ to $1.326 \mathrm{~mm}$ and yield stress ranging from 301.8 $\mathrm{MPa}$ to $324.6 \mathrm{MPa}$. It should, however, be noted that the above range of specimens were considered for the comparison of results.

For the case of flanges unfastened to the bearing plates, Table 7 shows the comparison of web crippling strength with design strength for the EOF loading condition. The current design standard NAS design strength do not considered $r_{\mathrm{i}} / t$ ratios greater than 3. In the British Standard and Eurocode comparison, the mean values of the ratios are 1.65 and 1.54 with the corresponding coefficients of variation $(\mathrm{COV})$ of 0.20 and 0.18 , respectively. 
For the case of flanges fastened to the bearing plates, Table 8 shows the comparison of web crippling strength with design strength for the EOF loading condition. The British Standard and Eurocodes provide unreliable web crippling strengths predictions for the case of flanges fastened. A comparison of these values with the corresponding experimental and numerical values indicates that although the British Standard and Eurocode values are lower bound, they are about $76 \%$ lower than the experimental and numerical failure loads. It is noted that British Standard and Eurocode are too conservative for the web crippling strengths of cold-formed steel lipped channel -sections without web holes. The current design standard NAS design strength do not considered $r_{\mathrm{i}} / t$ ratios greater than 3 .

\section{Comparison of experimental and numerical results with current design}

\section{strengths for cold-formed steel sections with web holes strength reduction factors}

As mentioned earlier, the current design standard NAS [7] provides design rules for web holes located at the mid-height of the specimen having a horizontal clear distance to the near edge of the bearing plates for the case of flanges fastened to the bearing plates. The web crippling strength predicted from test and FEA results were compared with the web crippling strength obtained from the current design standard NAS [7].

In accordance with NAS [7], for offset holes for the case where the flanges fastened to the bearing plates,

$$
R=1.01-0.325 \frac{a}{h}+0.083 \frac{x}{h} \leq 1.0
$$

where the limits for the reduction factor equation (1) are $\mathrm{N} \geq 25 \mathrm{~mm}, h / t \leq 200$, $a / h \leq 0.7$, clear distance between holes $\geq 457 \mathrm{~mm}$, distance between end of member and edge of holes $\geq \mathrm{d}, a \leq 152 \mathrm{~mm}$ and $\theta=90^{\circ}$. 
Furthermore, as mentioned by LaBoube et al. [6], who proposed the NAS [7] design expressions, there are limitations in the parameters, with the design equation limited to thickness ranging from $0.83 \mathrm{~mm}$ to $1.42 \mathrm{~mm}$ and yield stress ranging from $324 \mathrm{MPa}$ to $392 \mathrm{MPa}$. Only specimens within the above ranges were considered for the comparison described below.

Table 9 shows the comparison of web crippling strength with NAS design strength for an offset hole for the case of flanges fastened to the bearing plates. As can be seen, the value of $\mathrm{P}_{\mathrm{m}}$ is 1.03 with the corresponding $\mathrm{COV}$ of 0.03 i.e. the design strengths obtained from NAS are conservative and are on average only $3 \%$ lower than the experimental and finite element failure loads.

In Section 8 of this paper, four new strength reduction factor equations are proposed. These cover the EOF loading condition for centred and offset holes for the cases of both flanges unfastened and fastened to the bearing plates. It should be noted that although the NAS equation for an offset hole for the case of flanges fastened to the bearing plates are conservative and reasonable, the new equation proposed has a lower value of $\mathrm{P}_{\mathrm{m}}$ as well as covers a wider range of limits.

\section{Proposed strength reduction factors}

Comparing the failure loads of the channel sections having web holes with the sections without web holes, as shown in Tables 1 to 6 , it can be seen that, as expected, the failure load decreases as the size of the web holes increases. It can also been seen that the failure load increases slightly as the length of the bearing plates increases and the distance of the web holes increases.

Evaluation of the experimental and the numerical results show that the ratios $a / h$, $N / h$ and $x / h$ are the primary parameters influencing the web crippling behaviour of the sections with web holes. Therefore, based on both the experimental and the numerical 
results obtained from this study, four strength reduction factor $\left(R_{\mathrm{p}}\right)$ are proposed using bivariate linear regression analysis for the end-one-flange loading condition for the centred hole and offset hole, respectively.

For centred hole:

For the case where the flanges are unfastened to the bearing plates,

$$
R_{p}=0.96-0.34\left(\frac{a}{h}\right)+0.09\left(\frac{N}{h}\right) \leq 1
$$

For the case where the flanges are fastened to the bearing plates,

$$
R_{p}=0.93-0.41\left(\frac{a}{h}\right)+0.16\left(\frac{N}{h}\right) \leq 1
$$

For offset hole:

For the case where the flanges are unfastened to the bearing plates,

$$
R_{p}=0.97-0.26\left(\frac{a}{h}\right)+0.14\left(\frac{x}{h}\right) \leq 1
$$

For the case where the flanges are fastened to the bearing plates,

$$
R_{p}=0.97-0.14\left(\frac{a}{h}\right)+0.07\left(\frac{x}{h}\right) \leq 1
$$

The limits for the reduction factor in equations (2), (3), (4) and (5) are $h / t \leq 157.8$, $N / t \leq 120.97, N / h \leq 1.15, a / h \leq 0.8$, and $\theta=90^{\circ}$.

\section{Comparison of experimental and numerical results with proposed reduction}

\section{factor}

The values of the strength reduction factor $(R)$ obtained from the experimental and the numerical results are compared with the values of the proposed strength reduction factor $\left(R_{\mathrm{p}}\right)$ calculated using Eqs. (2), (3), (4) and (5) as plotted against the ratios $a / h$ and $h / t$ in Figs. 7 to 10 , respectively. Tables 10 to 13 summarize a statistical analysis to define the accuracy of the proposed design equations. It is shown that the proposed 
reduction factors are generally conservative and agree with the experimental and numerical results for both cases.

For the centred hole, the mean value of the web crippling reduction factor ratios are 1.00 and 1.00 for the case of flanges unfastened and fastened to the bearing plates, respectively. The corresponding values of $\mathrm{COV}$ are 0.09 and 0.09 , respectively; similarly, the reliability index values are $(\beta)$ of 2.69 and 2.69 , respectively.

For the offset hole, the mean value of the web crippling reduction factor ratios are 1.00 and 1.01 for the case of flanges unfastened and fastened to the bearing plates, respectively. The corresponding values of $\mathrm{COV}$ are 0.04 and 0.03 , respectively; similarly, the reliability index values are $(\beta)$ of 2.86 and 2.91 , respectively. Thus, the proposed strength reduction factor equations are able to predict the influence of the web holes on the web crippling strengths of channel sections for the EOF loading condition.

\section{Conclusions}

A parametric study of lipped channel sections having circular web holes subjected to end-one-flange (EOF) web crippling loading condition, where circular web holes are located at the mid-depth of the webs and centred above the bearing plates or with a horizontal clear distance to the near edge of the bearing plates, have been presented. Non-linear finite element models were used in the parametric study, which has been verified against the test results. Evaluation of the experimental and the numerical results show that ratio $a / h, N / h$ and $x / h$ are the primary parameters that influence the web crippling behaviour of the sections with web holes. In order to determine the effect of the ratio $a / h, N / h$ and $x / h$ on the web crippling strength, parametric studies were carried out considering the web holes, the cross-section sizes and the different bearing plate lengths. 
The web crippling strengths of cold-formed channel sections without holes obtained from tests and finite element analyses were compared with the current design strengths calculated from NAS [7], British Standards [16], and Eurocodes [17]. The British Standards and Eurocodes underestimate the web crippling strengths by around $76 \%$ and the current design code NAS design strength does not consider $r_{i} / t$ ratios greater than 3. It is shown that Eurocode and British Standard are very conservative for the web crippling strengths of cold-formed lipped channel sections without web holes.

Only NAS provides reduction factors for the case of circular holes with a horizontal clear distance to the near edge of bearing plates and only for the case of flanges fastened to the bearing plates. The design strengths obtained from NAS are $3 \%$ lower than the experimental and finite element failure loads, which shows that NAS provides reasonable prediction for the web crippling behaviour of cold-formed steel channel -sections with web holes. In this paper, modified coefficients are proposed that have been shown to cover a wider range of section parameters than the NAS coefficients.

Based on 74 test results and 638 numerical results, four new web crippling strength reduction factor equations were proposed for the EOF loading condition for the cases of both flanges unfastened and fastened to the bearing plates. Reliability analysis was performed to evaluate the reliability of the proposed strength reduction factors. It is shown that the proposed strength reduction factors are generally conservative and agree well with the experimental and numerical results. The proposed strength reduction factors are capable of producing reliable limit state design when calibrated with the resistance factor of $0.85(\phi=0.85)$. 


\section{Acknowledgements}

The authors gratefully acknowledge the support given by Metsec Plc, UK, for providing the materials and to Mr Burns and Professor Jim Rhodes for arranging the materials provided. 


\section{References}

[1] A. Uzzaman, J.B.P. Lim, D. Nash, J. Rhodes, B. Young, Web crippling behaviour of cold-formed steel channel sections with offset web holes subjected to interior-twoflange loading, Thin-Walled Structures, 50 (2012) 76-86.

[2] A. Uzzaman, J.B.P. Lim, D. Nash, J. Rhodes, B. Young, Effect of offset web holes on web crippling strength of cold-formed steel channel sections under end-two-flange loading condition, Thin-Walled Structures, 65 (2013) 34-48.

[3] A. Uzzaman, J.B.P. Lim, D. Nash, J. Rhodes, B. Young, Cold-formed steel sections with web openings subjected to web crippling under two-flange loading conditions-part I: Tests and finite element analysis, Thin-Walled Structures, 56 (2012) 38-48.

[4] A. Uzzaman, J.B.P. Lim, D. Nash, J. Rhodes, B. Young, Cold-formed steel sections with web openings subjected to web crippling under two-flange loading conditions-part II: Parametric study and proposed design equations, Thin-Walled Structures, 56 (2012) 79-87.

[5] Y. Lian, A. Uzzaman, J.B.P. Lim, G. Abdelal, W. Sha, D. Nash, B. Young, Effect of web holes on web crippling strength of cold-formed steel channel sections under endone-flange loading condition - Part I: Tests and finite element analysis. Submitted to Thin-walled Structures.

[6] R.A. LaBoube, W.W. Yu, S.U. Deshmukh, C.A. Uphoff, Crippling capacity of web elements with openings, Journal of Structural Engineering, 125 (1999) 137-141. 
[7] NAS, North American specification for the design of cold-formed steel structural members, American Iron and Steel Institute, AISI S100-2007, AISI Standard, 2007.

[8] W.W. Yu, C.S. Davis, Cold-formed steel members with perforated elements, Journal of the Structural Division, 99 (1973) 2061-2077.

[9] K.S. Sivakumaran, K.M. Zielonka, Web crippling strength of thin-walled steel members with web opening, Thin-Walled Structures, 8 (1989) 295-319.

[10] F. Zhou, B. Young, Web crippling of aluminium tubes with perforated webs, Engineering Structures, 32 (2010) 1397-1410.

[11] P. Natario, N. Silvestre, D. Camotim, Computational modelling of flange crushing in cold-formed steel sections, Thin-Walled Structures, 84 (2014) 393-405.

[12] P. Keerthan, M. Mahendran, E. Steau, Experimental study of web crippling behaviour of hollow flange channel beams under two flange load cases, Thin-Walled Structures, 85 (2014) 207-219.

[13] Y. Chen, XX. Chen, CY. Wang, Experimental and finite element analysis research on cold-formed steel lipped channel beams under web crippling, Thin-walled Structures, 87 (2015) 41-52.

[14] Y. Chen, XX. Chen, CY. Wang, Aluminum tubular sections subjected to web crippling, Thin-Walled Structures, 90 (2015) 49-60. 
[15] ABAQUS Analysis User's Manual-Version 6.13-1. ABAQUS Inc., USA, 2013.

[16] BS5950, Structural use of steelwork in buildings, in: Part 5 Code of practice for the design of cold-formed sections, British Standards Institution, London, 1998.

[17] Eurocode-3, Design of steel structures: Part 1.3: General rules — Supplementary rules for cold-formed thin gauge members and sheeting, in: ENV 1993-1-3, European Committee for Standardization, Brussels, Belgium, 1996.

[18] J.B.P. Lim, D.A. Nethercot, Finite element idealisation of a cold-formed steel portal frame, Journal of structural engineering, 130 (2004) 78-94.

[19] J.B.P. Lim, D.A. Nethercot, Stiffness prediction for bolted moment-connections between cold-formed steel members, Journal of constructional steel research, 60 (2004) 85-107.

[20] ASCE, Minimum design loads for buildings and other structures, in American Society of Civil Engineers Standard, New York, 2005.

[21] B. Beshara, R. M. Schuster, Web crippling data and calibrations of cold formed steel members, University of Waterloo, Canada, 2000. 
Table 1

Dimensions and web crippling strengths predicted from finite element analysis in parametric study of $a / h$ for centred hole where flanges unfastened to bearing plates

\begin{tabular}{|c|c|c|c|c|c|c|c|c|c|c|}
\hline \multirow[t]{2}{*}{ Specimen } & \multirow{2}{*}{$\begin{array}{c}\text { Web } \\
\mathrm{d} \\
(\mathrm{mm})\end{array}$} & \multirow{2}{*}{$\begin{array}{c}\text { Flange } \\
\text { bf } \\
(\mathrm{mm})\end{array}$} & \multirow{2}{*}{$\begin{array}{l}\text { Lip } \\
\text { bl } \\
(\mathrm{mm})\end{array}$} & \multirow{2}{*}{$\begin{array}{c}\text { Thickness } \\
\text { t } \\
(\mathrm{mm})\end{array}$} & \multirow{2}{*}{$\begin{array}{l}\text { Length } \\
\qquad \begin{array}{c}\text { L } \\
(\mathrm{mm})\end{array}\end{array}$} & \multicolumn{5}{|c|}{ FEA load per web, PFEA } \\
\hline & & & & & & $\begin{array}{c}\mathrm{A} 0 \\
(\mathrm{kN})\end{array}$ & $\begin{array}{l}\mathrm{A} 0.2 \\
(\mathrm{kN})\end{array}$ & $\begin{array}{l}\mathrm{A} 0.4 \\
(\mathrm{kN})\end{array}$ & $\begin{array}{l}\mathrm{A} 0.6 \\
(\mathrm{kN})\end{array}$ & $\begin{array}{l}\mathrm{A} 0.8 \\
(\mathrm{kN})\end{array}$ \\
\hline 142x60x13-t1.3-N100-FR & 142.70 & 59.79 & 13.23 & 1.23 & 720.0 & 4.77 & 4.58 & 3.96 & 3.26 & - \\
\hline $142 \times 60 \times 13-t 4.0-\mathrm{N} 100-\mathrm{FR}$ & 142.70 & 59.79 & 13.23 & 4.00 & 720.0 & 41.69 & 41.37 & 39.31 & 32.77 & - \\
\hline 142x60x13-t6.0-N100-FR & 142.70 & 59.79 & 13.23 & 6.00 & 720.0 & 68.73 & 68.61 & 68.15 & 65.39 & - \\
\hline 142x60x13-t1.3-N120-FR & 142.09 & 60.07 & 13.34 & 1.25 & 760.0 & 5.33 & 5.14 & 4.48 & 3.74 & - \\
\hline $142 \times 60 \times 13-t 4.0-\mathrm{N} 120-\mathrm{FR}$ & 142.09 & 60.07 & 13.34 & 4.00 & 760.0 & 41.77 & 41.59 & 39.89 & 36.60 & - \\
\hline 142x60x13-t6.0-N120-FR & 142.09 & 60.07 & 13.34 & 6.00 & 760.0 & 68.90 & 68.78 & 68.39 & 66.16 & - \\
\hline 142x60x13-t1.3-N150-FR & 142.15 & 60.06 & 13.27 & 1.24 & 820.0 & 5.64 & 5.26 & 4.68 & 4.00 & 3.32 \\
\hline $142 \times 60 \times 13-\mathrm{t} 4.0-\mathrm{N} 150-\mathrm{FR}$ & 142.15 & 60.06 & 13.27 & 4.00 & 820.0 & 42.30 & 41.92 & 41.49 & 40.17 & 36.80 \\
\hline 142x60x13-t6.0-N150-FR & 142.15 & 60.06 & 13.27 & 6.00 & 820.0 & 69.05 & 68.84 & 68.49 & 67.64 & 65.31 \\
\hline $202 \times 65 \times 15-\mathrm{t} 1.4-\mathrm{N} 100-\mathrm{FR}$ & 201.99 & 65.36 & 14.84 & 1.35 & 900.0 & 4.52 & 4.09 & 3.57 & - & - \\
\hline $202 \times 65 \times 15-t 4.0-N 100-F R$ & 201.99 & 65.36 & 14.84 & 4.00 & 900.0 & 40.67 & 38.64 & 32.12 & - & - \\
\hline $202 \times 65 \times 15-t 6.0-N 100-F R$ & 201.99 & 65.36 & 14.84 & 6.00 & 900.0 & 73.33 & 72.84 & 68.51 & - & - \\
\hline $202 \times 65 \times 15-\mathrm{t} 1.4-\mathrm{N} 120-\mathrm{FR}$ & 202.07 & 65.37 & 14.85 & 1.35 & 940.0 & 4.62 & 4.49 & 3.98 & 3.14 & - \\
\hline $202 \times 65 \times 15-\mathrm{t} 4.0-\mathrm{N} 120-\mathrm{FR}$ & 202.07 & 65.37 & 14.85 & 4.00 & 940.0 & 40.97 & 40.50 & 35.34 & 26.78 & - \\
\hline $202 \times 65 \times 15-t 6.0-N 120-F R$ & 202.07 & 65.37 & 14.85 & 6.00 & 940.0 & 73.74 & 73.37 & 70.51 & 58.43 & - \\
\hline $202 \times 65 \times 15-t 1.4-N 150-F R$ & 202.13 & 65.40 & 14.72 & 1.35 & 940.0 & 5.02 & 4.73 & 4.24 & 3.48 & - \\
\hline $202 \times 65 \times 15-t 4.0-N 150-F R$ & 202.06 & 65.25 & 14.52 & 4.00 & 940.0 & 41.51 & 41.24 & 39.33 & 31.58 & - \\
\hline $202 \times 65 \times 15-\mathrm{t} 6.0-\mathrm{N} 150-\mathrm{FR}$ & 202.06 & 65.25 & 14.52 & 6.00 & 940.0 & 74.13 & 73.58 & 72.40 & 67.34 & - \\
\hline $302 \times 90 \times 18-\mathrm{t} 2.0-\mathrm{N} 100-\mathrm{FR}$ & 303.42 & 88.20 & 18.56 & 1.90 & 1199.0 & 8.36 & 8.07 & - & - & - \\
\hline 302x90x18-t4.0-N100-FR & 303.42 & 88.20 & 18.56 & 4.00 & 1199.0 & 43.30 & 40.76 & - & - & - \\
\hline 302x90x18-t6.0-N100-FR & 303.42 & 88.20 & 18.56 & 6.00 & 1199.0 & 81.63 & 81.51 & - & - & - \\
\hline $302 \times 90 \times 18-\mathrm{t} 2.0-\mathrm{N} 120-\mathrm{FR}$ & 302.35 & 89.08 & 18.61 & 1.90 & 1238.8 & 8.61 & 8.30 & 7.67 & - & - \\
\hline 302x90x18-t4.0-N120-FR & 302.35 & 89.08 & 18.61 & 4.00 & 1238.8 & 44.69 & 42.14 & 36.08 & - & - \\
\hline 302x90x18-t6.0-N120-FR & 302.35 & 89.08 & 18.61 & 6.00 & 1238.8 & 82.43 & 81.80 & 78.45 & - & - \\
\hline $302 \times 90 \times 18-t 2.0-\mathrm{N} 150-\mathrm{FR}$ & 303.37 & 88.86 & 18.45 & 1.90 & 1299.9 & 9.17 & 8.80 & 8.30 & - & - \\
\hline $302 \times 90 \times 18-\mathrm{t} 4.0-\mathrm{N} 150-\mathrm{FR}$ & 303.37 & 88.86 & 18.45 & 4.00 & 1299.9 & 46.63 & 44.12 & 38.30 & - & - \\
\hline $302 \times 90 \times 18-t 6.0-\mathrm{N} 150-\mathrm{FR}$ & 303.37 & 88.86 & 18.45 & 6.00 & 1299.9 & 83.29 & 82.37 & 81.44 & - & - \\
\hline
\end{tabular}


Table 2

Dimensions and web crippling strengths predicted from finite element analysis in parametric study of $a / h$ for centred hole where flanges fastened to bearing plates

\begin{tabular}{|c|c|c|c|c|c|c|c|c|c|c|}
\hline \multirow[t]{2}{*}{ Specimen } & \multirow{2}{*}{$\begin{array}{c}\text { Web } \\
\mathrm{d} \\
(\mathrm{mm})\end{array}$} & \multirow{2}{*}{$\begin{array}{c}\text { Flange } \\
\text { bf } \\
(\mathrm{mm})\end{array}$} & \multirow{2}{*}{$\begin{array}{c}\text { Lip } \\
\text { bl } \\
(\mathrm{mm})\end{array}$} & \multirow{2}{*}{$\begin{array}{c}\text { Thickness } \\
\mathrm{t} \\
(\mathrm{mm})\end{array}$} & \multirow{2}{*}{$\begin{array}{c}\text { Length } \\
\mathrm{L} \\
(\mathrm{mm})\end{array}$} & \multicolumn{5}{|c|}{ FEA load per web, PFEA } \\
\hline & & & & & & $\begin{array}{c}\mathrm{A} 0 \\
(\mathrm{kN})\end{array}$ & $\begin{array}{l}\mathrm{A} 0.2 \\
(\mathrm{kN})\end{array}$ & $\begin{array}{l}\mathrm{A} 0.4 \\
(\mathrm{kN})\end{array}$ & $\begin{array}{l}\text { A0.6 } \\
(\mathrm{kN})\end{array}$ & $\begin{array}{l}\mathrm{A} 0.8 \\
(\mathrm{kN})\end{array}$ \\
\hline EOF142x60x13-t1.3N100FX & 142.13 & 60.06 & 13.17 & 1.27 & 720.0 & 7.06 & 6.81 & 5.80 & 5.17 & - \\
\hline EOF142x60x13-t4.0N100FX & 142.13 & 60.06 & 13.17 & 4.00 & 720.0 & 55.41 & 55.34 & 55.05 & 48.91 & - \\
\hline EOF142x60x13-t6.0N100FX & 142.13 & 60.06 & 13.17 & 6.00 & 720.0 & 94.77 & 94.53 & 93.74 & 89.26 & - \\
\hline EOF142x60x13-t1.3N120FX & 142.15 & 60.09 & 13.06 & 1.24 & 760.0 & 7.28 & 7.01 & 6.24 & 5.42 & - \\
\hline EOF142x60x13-t4.0N120FX & 142.15 & 60.09 & 13.06 & 4.00 & 760.0 & 55.79 & 55.75 & 55.59 & 54.09 & - \\
\hline EOF142x60x13-t6.0N120FX & 142.15 & 60.09 & 13.06 & 6.00 & 760.0 & 94.88 & 94.69 & 94.09 & 92.58 & - \\
\hline EOF142x60x13-t1.3N150FX & 142.27 & 59.99 & 13.14 & 1.23 & 820.0 & 7.95 & 7.65 & 6.96 & 6.23 & 5.36 \\
\hline EOF142x60x13-t4.0N150FX & 142.27 & 59.99 & 13.14 & 4.00 & 820.0 & 56.55 & 56.52 & 56.41 & 56.16 & 51.38 \\
\hline EOF142x60x13-t6.0N150FX & 142.27 & 59.99 & 13.14 & 6.00 & 820.0 & 95.01 & 94.86 & 94.38 & 93.36 & 88.50 \\
\hline EOF $202 \times 65 \times 15-t 1.4 N 100 F X$ & 202.01 & 65.57 & 14.51 & 1.40 & 900.0 & 7.14 & 6.84 & 5.87 & - & - \\
\hline EOF202x65x15-t4.0N100FX & 202.01 & 65.57 & 14.51 & 4.00 & 900.0 & 64.39 & 60.49 & 50.54 & - & - \\
\hline EOF202x65x15-t6.0N100FX & 202.01 & 65.57 & 14.51 & 6.00 & 900.0 & 116.67 & 115.92 & 108.08 & - & - \\
\hline EOF $202 \times 65 \times 15-t 1.4 N 120 F X$ & 202.02 & 65.39 & 14.71 & 1.40 & 939.0 & 7.61 & 7.33 & 6.40 & 5.22 & - \\
\hline EOF202x65x15-t4.0N120FX & 202.02 & 65.39 & 14.71 & 4.00 & 939.0 & 67.71 & 64.66 & 56.55 & 41.43 & - \\
\hline EOF202x65x15-t6.0N120FX & 202.02 & 65.39 & 14.71 & 6.00 & 939.0 & 116.82 & 116.34 & 113.70 & 83.24 & - \\
\hline EOF $202 \times 65 \times 15-t 1.4 N 150 F X$ & 202.01 & 65.45 & 14.75 & 1.40 & 999.0 & 8.41 & 8.09 & 7.16 & 5.94 & - \\
\hline EOF202x65x15-t4.0N150FX & 202.01 & 65.45 & 14.75 & 4.00 & 999.0 & 67.87 & 66.82 & 62.65 & 53.28 & - \\
\hline EOF202x65x15-t6.0N150FX & 202.01 & 65.45 & 14.75 & 6.00 & 999.0 & 117.67 & 117.34 & 116.14 & 110.71 & - \\
\hline EOF302x90x18-t2.0N100FX & 302.91 & 88.61 & 18.66 & 1.90 & 1199.6 & 13.11 & 12.66 & - & - & - \\
\hline EOF302x90x 18-t4.0N100FX & 302.91 & 88.61 & 18.66 & 4.00 & 1199.6 & 63.26 & 59.64 & - & - & - \\
\hline EOF302x90x18-t6.0N100FX & 302.91 & 88.61 & 18.66 & 6.00 & 1199.6 & 147.09 & 136.65 & - & - & - \\
\hline EOF302x90x18-t2.0N120FX & 303.36 & 89.06 & 18.79 & 1.90 & 1242.0 & 13.91 & 13.37 & 10.83 & - & - \\
\hline EOF302x90x18-t4.0N120FX & 303.36 & 89.06 & 18.79 & 4.00 & 1242.0 & 67.88 & 63.57 & 50.64 & - & - \\
\hline EOF302x90x18-t6.0N120FX & 303.36 & 89.06 & 18.79 & 6.00 & 1242.0 & 155.93 & 145.39 & 115.16 & - & - \\
\hline EOF302x90x18-t2.0N150FX & 303.36 & 88.65 & 18.63 & 1.90 & 1298.0 & 15.43 & 14.82 & 12.23 & - & - \\
\hline EOF302x90x18-t4.0N150FX & 303.36 & 88.65 & 18.63 & 4.00 & 1298.0 & 74.35 & 69.59 & 56.96 & - & - \\
\hline EOF302x90x 18-t6.0N150FX & 303.36 & 88.65 & 18.63 & 6.00 & 1298.0 & 156.97 & 153.97 & 128.88 & - & - \\
\hline
\end{tabular}


Table 3

Dimensions and web crippling strengths predicted from finite element analysis in parametric study of $a / h$ for offset hole where flanges unfastened to bearing plates

\begin{tabular}{|c|c|c|c|c|c|c|c|c|c|}
\hline \multirow[t]{2}{*}{ Specimen } & \multirow{2}{*}{$\begin{array}{c}\text { Web } \\
\mathrm{d} \\
(\mathrm{mm})\end{array}$} & \multirow{2}{*}{$\begin{array}{c}\text { Flange } \\
\mathrm{bf} \\
(\mathrm{mm})\end{array}$} & \multirow{2}{*}{$\begin{array}{c}\text { Lip } \\
\text { bl } \\
(\mathrm{mm})\end{array}$} & \multirow{2}{*}{$\begin{array}{c}\text { Thickness } \\
\mathrm{t} \\
(\mathrm{mm})\end{array}$} & \multirow{2}{*}{$\begin{array}{l}\text { Length } \\
\qquad \begin{array}{c}\mathrm{L} \\
(\mathrm{mm})\end{array}\end{array}$} & \multicolumn{4}{|c|}{ FEA load per web, PFEA } \\
\hline & & & & & & $\begin{array}{c}\mathrm{A} 0 \\
(\mathrm{kN})\end{array}$ & $\begin{array}{l}\mathrm{A} 0.2 \\
(\mathrm{kN})\end{array}$ & $\begin{array}{l}\mathrm{A} 0.4 \\
(\mathrm{kN})\end{array}$ & $\begin{array}{l}\mathrm{A} 0.6 \\
(\mathrm{kN})\end{array}$ \\
\hline $142 \times 60 \times 13-\mathrm{t} 1.3-\mathrm{N} 100-\mathrm{FR}$ & 142.70 & 59.79 & 13.23 & 1.23 & 720.0 & 4.77 & 4.71 & 4.62 & 4.47 \\
\hline $142 \times 60 \times 13-\mathrm{t} 4.0-\mathrm{N} 100-\mathrm{FR}$ & 142.70 & 59.79 & 13.23 & 4.00 & 720.0 & 41.69 & 41.61 & 41.28 & 38.25 \\
\hline $142 \times 60 \times 13-t 6.0-N 100-F R$ & 142.70 & 59.79 & 13.23 & 6.00 & 720.0 & 68.73 & 68.61 & 68.14 & 65.60 \\
\hline $142 \times 60 \times 13-\mathrm{t} 1.3-\mathrm{N} 120-\mathrm{FR}$ & 142.09 & 60.07 & 13.34 & 1.25 & 760.0 & 5.33 & 5.30 & 5.06 & 4.90 \\
\hline $142 \times 60 \times 13-\mathrm{t} 4.0-\mathrm{N} 120-\mathrm{FR}$ & 142.09 & 60.07 & 13.34 & 4.00 & 760.0 & 41.77 & 41.69 & 41.38 & 39.65 \\
\hline $142 \times 60 \times 13-t 6.0-\mathrm{N} 120-\mathrm{FR}$ & 142.09 & 60.07 & 13.34 & 6.00 & 760.0 & 68.90 & 68.79 & 68.42 & 66.18 \\
\hline 142x60x13-t1.3-N150-FR & 142.15 & 60.06 & 36.64 & 1.24 & 820.0 & 5.64 & 5.43 & 5.38 & 5.19 \\
\hline $142 \times 60 \times 13-\mathrm{t} 4.0-\mathrm{N} 150-\mathrm{FR}$ & 142.15 & 60.06 & 36.64 & 4.00 & 820.0 & 42.30 & 42.23 & 41.84 & 40.79 \\
\hline $142 \times 60 \times 13-t 6.0-\mathrm{N} 150-\mathrm{FR}$ & 142.15 & 60.06 & 36.64 & 6.00 & 820.0 & 69.05 & 68.95 & 68.52 & 67.68 \\
\hline $202 \times 65 \times 15-\mathrm{t} 1.4-\mathrm{N} 100-\mathrm{FR}$ & 201.99 & 65.36 & 14.84 & 1.35 & 900.0 & 4.52 & 4.45 & 4.25 & 4.00 \\
\hline $202 \times 65 \times 15-\mathrm{t} 4.0-\mathrm{N} 100-\mathrm{FR}$ & 201.99 & 65.36 & 14.84 & 1.35 & 900.0 & 40.67 & 40.54 & 39.24 & 36.93 \\
\hline $202 \times 65 \times 15-\mathrm{t} 6.0-\mathrm{N} 100-\mathrm{FR}$ & 201.99 & 65.36 & 14.84 & 1.35 & 900.0 & 73.33 & 73.24 & 72.24 & 68.88 \\
\hline $202 \times 65 \times 15-\mathrm{t} 1.4-\mathrm{N} 120-\mathrm{FR}$ & 202.07 & 65.37 & 14.85 & 1.35 & 940.0 & 4.62 & 4.60 & 4.51 & 4.26 \\
\hline $202 \times 65 \times 15-\mathrm{t} 4.0-\mathrm{N} 120-\mathrm{FR}$ & 202.07 & 65.37 & 14.85 & 4.00 & 940.0 & 40.97 & 40.69 & 39.82 & 37.05 \\
\hline $202 \times 65 \times 15-\mathrm{t} 6.0-\mathrm{N} 120-\mathrm{FR}$ & 202.07 & 65.37 & 14.85 & 6.00 & 940.0 & 73.74 & 73.51 & 72.72 & 69.34 \\
\hline $202 \times 65 \times 15-t 1.4-N 150-F R$ & 202.13 & 65.40 & 14.72 & 1.35 & 1000.0 & 5.02 & 4.97 & 4.80 & 4.60 \\
\hline $202 \times 65 \times 15-\mathrm{t} 4.0-\mathrm{N} 150-\mathrm{FR}$ & 202.13 & 65.40 & 14.72 & 4.00 & 1000.0 & 41.51 & 41.37 & 40.72 & 38.69 \\
\hline $202 \times 65 \times 15-\mathrm{t} 6.0-\mathrm{N} 150-\mathrm{FR}$ & 202.13 & 65.40 & 14.72 & 6.00 & 1000.0 & 74.13 & 73.93 & 73.12 & 70.21 \\
\hline $302 \times 90 \times 18-\mathrm{t} 2.0-\mathrm{N} 100-\mathrm{FR}$ & 303.42 & 88.20 & 18.56 & 1.90 & 1199.0 & 8.36 & 8.26 & 7.92 & 7.37 \\
\hline $302 \times 90 \times 18-t 4.0-\mathrm{N} 100-\mathrm{FR}$ & 303.42 & 88.20 & 18.56 & 4.00 & 1199.0 & 43.30 & 42.86 & 41.71 & 40.04 \\
\hline 302x90x18-t6.0-N100-FR & 303.42 & 88.20 & 18.56 & 6.00 & 1199.0 & 81.63 & 81.54 & 80.14 & 77.24 \\
\hline $302 \times 90 \times 18-\mathrm{t} 2.0-\mathrm{N} 120-\mathrm{FR}$ & 302.35 & 89.08 & 18.61 & 1.90 & 1238.8 & 8.61 & 8.51 & 8.37 & 8.10 \\
\hline $302 \times 90 \times 18-t 4.0-N 120-F R$ & 302.35 & 89.08 & 18.61 & 4.00 & 1238.8 & 44.69 & 44.25 & 43.66 & 42.72 \\
\hline 302x90x18-t6.0-N120-FR & 302.35 & 89.08 & 18.61 & 6.00 & 1238.8 & 82.43 & 82.15 & 81.33 & 79.01 \\
\hline $302 \times 90 \times 18-\mathrm{t} 2.0-\mathrm{N} 150-\mathrm{FR}$ & 303.37 & 88.86 & 18.45 & 1.90 & 1299.9 & 9.17 & 9.13 & 8.80 & 8.60 \\
\hline $302 \times 90 \times 18-\mathrm{t} 4.0-\mathrm{N} 150-\mathrm{FR}$ & 303.37 & 88.86 & 18.45 & 4.00 & 1299.9 & 46.63 & 46.23 & 45.29 & 43.95 \\
\hline $302 \times 90 \times 18-t 6.0-N 150-F R$ & 303.37 & 88.86 & 18.45 & 6.00 & 1299.9 & 83.29 & 82.97 & 81.85 & 79.30 \\
\hline
\end{tabular}


Table 4

Dimensions and web crippling strengths predicted from finite element analysis in parametric study of $a / h$ for offset hole where flanges fastened to bearing plates

\begin{tabular}{|c|c|c|c|c|c|c|c|c|c|}
\hline \multirow[t]{2}{*}{ Specimen } & \multirow{2}{*}{$\begin{array}{c}\text { Web } \\
\text { d } \\
(\mathrm{mm})\end{array}$} & \multirow{2}{*}{$\begin{array}{c}\text { Flange } \\
\text { bf } \\
(\mathrm{mm})\end{array}$} & \multirow{2}{*}{$\begin{array}{c}\text { Lip } \\
\text { bl } \\
(\mathrm{mm})\end{array}$} & \multirow{2}{*}{$\begin{array}{c}\text { Thickness } \\
\mathrm{t} \\
(\mathrm{mm})\end{array}$} & \multirow{2}{*}{$\begin{array}{l}\text { Length } \\
\qquad \begin{array}{c}\mathrm{L} \\
(\mathrm{mm})\end{array}\end{array}$} & \multicolumn{4}{|c|}{ FEA load per web, PFEA } \\
\hline & & & & & & $\begin{array}{c}\mathrm{A} 0 \\
(\mathrm{kN})\end{array}$ & $\begin{array}{l}\mathrm{A} 0.2 \\
(\mathrm{kN})\end{array}$ & $\begin{array}{l}\text { A0.4 } \\
(\mathrm{kN})\end{array}$ & $\begin{array}{l}\mathrm{A} 0.6 \\
(\mathrm{kN})\end{array}$ \\
\hline EOF142x60x13-t1.3N100FX & 142.13 & 60.06 & 13.17 & 1.27 & 720.0 & 7.06 & 7.02 & 6.88 & 6.68 \\
\hline EOF142x60x13-t4.0N100FX & 142.13 & 60.06 & 13.17 & 4.00 & 720.0 & 55.41 & 55.32 & 54.97 & 48.45 \\
\hline EOF142x60x13-t6.0N100FX & 142.13 & 60.06 & 13.17 & 6.00 & 720.0 & 94.77 & 94.37 & 92.76 & 80.36 \\
\hline EOF142x60x13-t1.3N120FX & 142.15 & 60.09 & 13.06 & 1.24 & 760.0 & 7.28 & 7.24 & 7.11 & 6.92 \\
\hline EOF142x60x13-t4.0N120FX & 142.15 & 60.09 & 13.06 & 4.00 & 760.0 & 55.79 & 55.70 & 55.30 & 48.88 \\
\hline EOF142x60x13-t6.0N120FX & 142.15 & 60.09 & 13.06 & 6.00 & 760.0 & 94.88 & 94.46 & 92.98 & 80.68 \\
\hline EOF142x60x13-t1.3N150FX & 142.27 & 59.99 & 13.14 & 1.23 & 820.0 & 7.95 & 7.92 & 7.82 & 7.62 \\
\hline EOF142x60x13-t4.0N150FX & 142.27 & 59.99 & 13.14 & 4.00 & 820.0 & 56.55 & 56.45 & 55.93 & 49.33 \\
\hline EOF142x60x13-t6.0N150FX & 142.27 & 59.99 & 13.14 & 6.00 & 820.0 & 95.01 & 94.56 & 93.09 & 80.97 \\
\hline EOF $202 \times 65 \times 15-t 1.4 N 100 F X$ & 202.01 & 65.57 & 14.51 & 1.40 & 900.0 & 7.14 & 7.08 & 6.89 & 6.58 \\
\hline EOF $202 \times 65 \times 15-t 4.0 N 100 F X$ & 202.01 & 65.57 & 14.51 & 4.00 & 900.0 & 64.39 & 64.15 & 63.45 & 58.30 \\
\hline EOF $202 \times 65 \times 15-t 6.0 \mathrm{~N} 100 \mathrm{FX}$ & 202.01 & 65.57 & 14.51 & 6.00 & 900.0 & 116.67 & 116.09 & 114.32 & 100.46 \\
\hline EOF202x65x15-t1.4N120FX & 202.02 & 65.39 & 14.71 & 1.40 & 939.0 & 7.61 & 7.56 & 7.40 & 7.16 \\
\hline EOF $202 \times 65 \times 15-t 4.0 N 120 F X$ & 202.02 & 65.39 & 14.71 & 4.00 & 939.0 & 67.71 & 67.43 & 66.49 & 58.42 \\
\hline EOF202x65x15-t6.0N120FX & 202.02 & 65.39 & 14.71 & 6.00 & 939.0 & 116.82 & 116.26 & 114.37 & 100.69 \\
\hline EOF202x65x15-t1.4N150-FX & 202.01 & 65.45 & 14.75 & 1.40 & 999.0 & 8.41 & 8.38 & 8.21 & 7.93 \\
\hline EOF202x65x15-t4.0N150-FX & 202.01 & 65.45 & 14.75 & 4.00 & 999.0 & 67.87 & 67.57 & 66.58 & 58.68 \\
\hline EOF202x65x15-t6.0N150-FX & 202.01 & 65.45 & 14.75 & 6.00 & 999.0 & 117.67 & 117.12 & 116.00 & 110.97 \\
\hline EOF $302 \times 90 \times 18-t 2.0 \mathrm{~N} 100 \mathrm{FX}$ & 302.91 & 88.61 & 18.66 & 1.90 & 1199.6 & 13.11 & 12.87 & 12.41 & 12.05 \\
\hline EOF302x90x18-t4.0N100FX & 302.91 & 88.61 & 18.66 & 4.00 & 1199.6 & 63.26 & 62.95 & 62.16 & 60.97 \\
\hline EOF302x90x18-t6.0N100FX & 302.91 & 88.61 & 18.66 & 6.00 & 1199.6 & 147.09 & 146.58 & 145.31 & 136.52 \\
\hline EOF302x90x18-t2.0N120FX & 303.36 & 89.06 & 18.79 & 1.90 & 1242.0 & 13.91 & 13.77 & 13.53 & 13.14 \\
\hline EOF302x90x18-t4.0N120FX & 303.36 & 89.06 & 18.79 & 4.00 & 1242.0 & 67.88 & 67.60 & 66.91 & 65.64 \\
\hline EOF302x90x18-t6.0N120FX & 303.36 & 89.06 & 18.79 & 6.00 & 1242.0 & 155.93 & 155.32 & 153.58 & 144.15 \\
\hline EOF302x90x18-t2.0N150FX & 303.36 & 88.65 & 18.63 & 1.90 & 1298.0 & 15.43 & 15.34 & 15.11 & 14.60 \\
\hline EOF302x90x18-t4.0N150FX & 303.36 & 88.65 & 18.63 & 4.00 & 1298.0 & 74.35 & 74.13 & 73.54 & 71.70 \\
\hline EOF302x90x18-t6.0N150FX & 303.36 & 88.65 & 18.63 & 6.00 & 1298.0 & 156.97 & 156.38 & 154.46 & 145.27 \\
\hline
\end{tabular}


Table 5

Dimensions and web crippling strengths predicted from finite element analysis in parametric study of $x / h$ for offset hole where flanges unfastened to bearing plates

\begin{tabular}{|c|c|c|c|c|c|c|c|c|c|}
\hline \multirow[t]{2}{*}{ Specimen } & \multirow{2}{*}{$\begin{array}{c}\text { Web } \\
\mathrm{d} \\
(\mathrm{mm})\end{array}$} & \multirow{2}{*}{$\begin{array}{c}\text { Flange } \\
\text { bf } \\
(\mathrm{mm})\end{array}$} & \multirow{2}{*}{$\begin{array}{c}\text { Lip } \\
\text { bl } \\
(\mathrm{mm})\end{array}$} & \multirow{2}{*}{$\begin{array}{c}\text { Thickness } \\
\text { t } \\
(\mathrm{mm})\end{array}$} & \multirow{2}{*}{$\begin{array}{c}\text { Length } \\
\text { L } \\
(\mathrm{mm})\end{array}$} & \multicolumn{4}{|c|}{ FEA load per web, PFEA } \\
\hline & & & & & & $\begin{array}{c}\mathrm{X} 0 \\
(\mathrm{kN})\end{array}$ & $\begin{array}{l}\mathrm{X} 0.2 \\
(\mathrm{kN})\end{array}$ & $\begin{array}{l}\mathrm{X} 0.4 \\
(\mathrm{kN})\end{array}$ & $\begin{array}{l}\mathrm{X} 0.6 \\
(\mathrm{kN})\end{array}$ \\
\hline $142 \times 60 \times 13-\mathrm{t} 1.3-\mathrm{N} 100-\mathrm{A} 0.2-\mathrm{FR}$ & 142.70 & 59.79 & 13.23 & 1.23 & 720.0 & 4.58 & 4.66 & 4.68 & 4.69 \\
\hline $142 \times 60 \times 13-\mathrm{t} 1.3-\mathrm{N} 100-\mathrm{A} 0.4-\mathrm{FR}$ & 142.70 & 59.79 & 13.23 & 1.23 & 720.0 & 3.96 & 4.41 & 4.49 & 4.56 \\
\hline $142 \times 60 \times 13-\mathrm{t} 1.3-\mathrm{N} 120-\mathrm{A} 0.2-\mathrm{FR}$ & 142.09 & 60.07 & 13.34 & 1.25 & 760.0 & 5.14 & 5.24 & 5.26 & 5.28 \\
\hline 142x60x13-t1.3-N120-A0.4-FR & 142.09 & 60.07 & 13.34 & 1.25 & 760.0 & 4.48 & 4.84 & 4.91 & 4.98 \\
\hline $142 \times 60 \times 13-\mathrm{t} 1.3-\mathrm{N} 120-\mathrm{A} 0.6-\mathrm{FR}$ & 142.09 & 60.07 & 13.34 & 1.25 & 760.0 & 3.74 & 4.56 & 4.70 & 4.81 \\
\hline 142x60x13-t1.3-N150-A0-FR & 142.15 & 60.06 & 13.27 & 1.24 & 820.0 & 5.64 & 5.64 & 5.64 & 5.64 \\
\hline 142x60x13-t1.3-N150-A0.8-FR & 142.15 & 60.06 & 13.27 & 1.24 & 820.0 & 3.32 & 4.76 & 4.84 & 4.92 \\
\hline 202x65x15-t1.4-N100-A0-FR & 201.99 & 65.36 & 14.84 & 1.35 & 900.0 & 4.52 & 4.52 & 4.52 & 4.52 \\
\hline 202x65x15-t1.4-N100-A0.2-FR & 201.99 & 65.36 & 14.84 & 1.35 & 900.0 & 4.09 & 4.43 & 4.43 & 4.44 \\
\hline $202 \times 65 \times 15-\mathrm{t} 1.4-\mathrm{N} 100-\mathrm{A} 0.4-\mathrm{FR}$ & 201.99 & 65.36 & 14.84 & 1.35 & 900.0 & 3.57 & 4.14 & 4.18 & 4.22 \\
\hline 202x65x15-t1.4-N120-A0-FR & 202.07 & 65.37 & 14.85 & 1.35 & 940.0 & 4.62 & 4.62 & 4.62 & 4.62 \\
\hline $202 \times 65 \times 15-\mathrm{t} 1.4-\mathrm{N} 120-\mathrm{A} 0.2-\mathrm{FR}$ & 202.07 & 65.37 & 14.85 & 1.35 & 940.0 & 4.49 & 4.56 & 4.57 & 4.59 \\
\hline $202 \times 65 \times 15-\mathrm{t} 1.4-\mathrm{N} 120-\mathrm{A} 0.4-\mathrm{FR}$ & 202.07 & 65.37 & 14.85 & 1.35 & 940.0 & 3.98 & 4.37 & 4.42 & 4.48 \\
\hline 202x65x15-t1.4-N120-A0.6-FR & 202.07 & 65.37 & 14.85 & 1.35 & 940.0 & 3.14 & 3.98 & 4.13 & 4.22 \\
\hline 202x65x15-t1.4-N150-A0-FR & 202.13 & 65.40 & 14.72 & 1.35 & 1000.0 & 5.02 & 5.02 & 5.02 & 5.02 \\
\hline
\end{tabular}


$302 \times 90 \times 18-t 2.0-N 120-A 0.2-F R$

$302 \times 90 \times 18-\mathrm{t} 2.0-\mathrm{N} 120-\mathrm{A} 0.4-\mathrm{FR}$

302x90x18-t2.0-N150-A0-FR

302x90x18-t2.0-N150-A0.2-FR

302x90x 18-t2.0-N150-A0.4-FR
302.35

89.08

302.35

89.08

18.6

303.37

88.86

88.86

88.86
$18.45 \quad 1.90$

$18.45 \quad 1.90$
1238.8

1238.8

1299.9

1299.9

1299.9

8.30 
Table 6

Dimensions and web crippling strengths predicted from finite element analysis in parametric study of $x / h$ for offset hole where flanges fastened to bearing plates

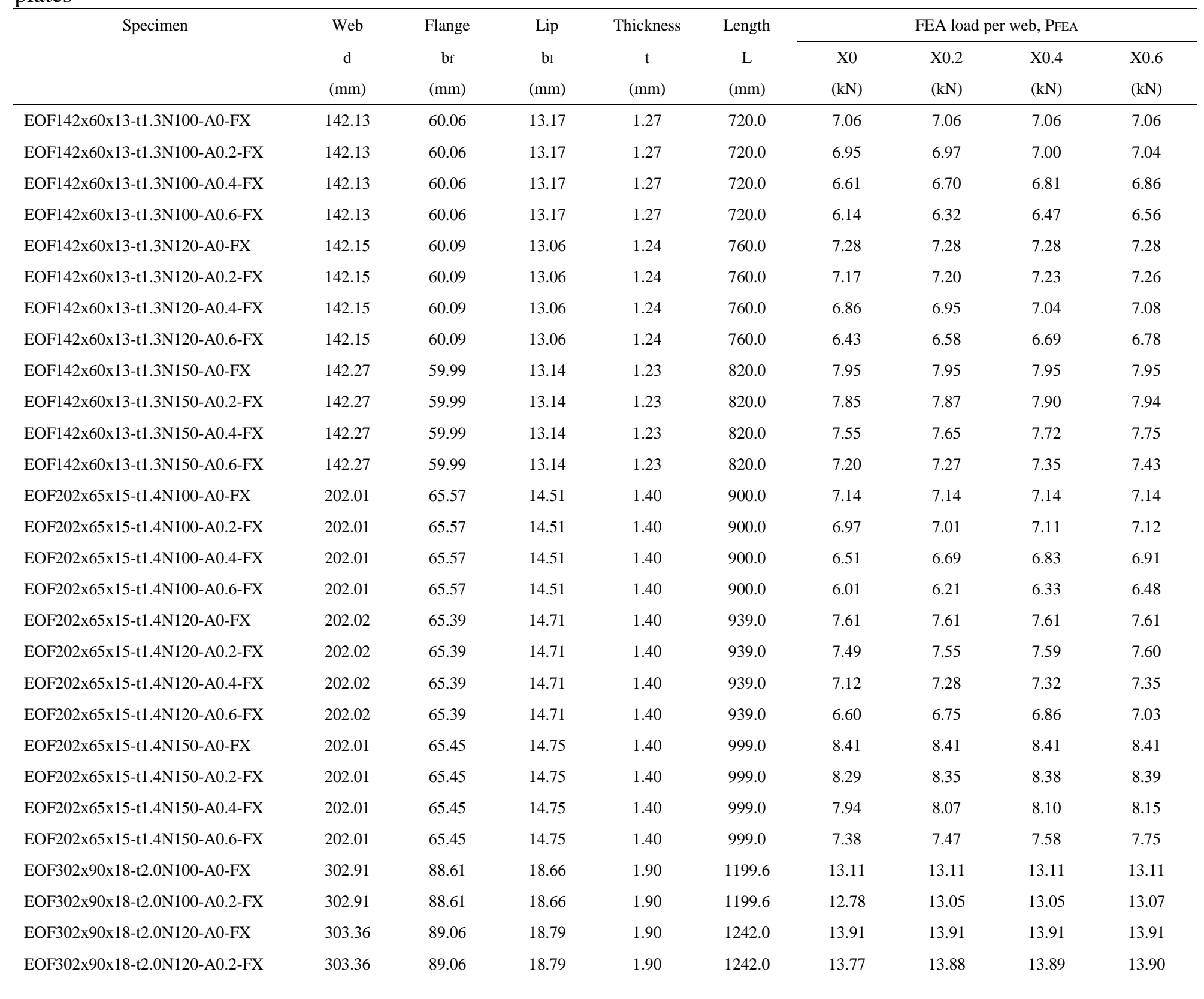


EOF302x90x18-t2.0N120-A0.4-FX

303.36

89.06

$18.79 \quad 1.90$

1242.0

13.03

13.31

13.39

13.47

EOF302x90x18-t2.0N150-A0-FX

303.36

88.65

18.63

1.90

1298.0

15.43

15.43

15.43

15.43

EOF302x90x18-t2.0N150-A0.2-FX

303.36

88.65

$18.63 \quad 1.90$

1298.0

14.55

14.65

14.70

15.01 
Table 7

Comparison of experimental and numerical results with design strength for case of flanges unfastened to bearing plates

\begin{tabular}{|c|c|c|c|c|c|c|c|c|c|c|c|}
\hline \multirow[t]{2}{*}{ Specimen } & \multirow{2}{*}{$\begin{array}{c}\text { Web } \\
\text { slenderness } \\
\text { h/t }\end{array}$} & \multirow{2}{*}{$\begin{array}{c}\text { Bearing } \\
\text { length } \\
\text { ratio } \\
\mathrm{N} / \mathrm{t}\end{array}$} & \multirow{2}{*}{$\begin{array}{c}\begin{array}{c}\text { Bearing } \\
\text { length } \\
\text { ratio }\end{array} \\
\mathrm{N} / \mathrm{h}\end{array}$} & \multirow{2}{*}{$\begin{array}{c}\text { Inside } \\
\text { bend } \\
\text { radius } \\
\text { ratio } \\
\text { ri/t }\end{array}$} & \multirow{2}{*}{$\begin{array}{c}\text { Failure } \\
\text { load per } \\
\text { web } \\
\left(\mathrm{P}_{\text {EXP }}\right) \\
\text { P } \\
(\mathrm{kN})\end{array}$} & \multicolumn{3}{|c|}{$\begin{array}{l}\text { Web crippling strength per } \\
\text { web predicted from current } \\
\text { design codes }\end{array}$} & \multicolumn{3}{|c|}{ Comparison } \\
\hline & & & & & & $\begin{array}{l}\mathrm{P}_{\mathrm{BS}} \\
(\mathrm{kN})\end{array}$ & $\begin{array}{l}P_{\text {Euro. }} \\
(\mathrm{kN})\end{array}$ & $\begin{array}{r}\mathrm{P}_{\mathrm{NAS}} \\
(\mathrm{kN})\end{array}$ & $\mathrm{P} / \mathrm{P}_{\mathrm{BS}}$ & $\mathrm{P} / \mathrm{P}_{\text {Euro }}$ & $\mathrm{P} / \mathrm{P}_{\mathrm{NAS}}$ \\
\hline 142x60x13-t1.3-N100-A0-FR-T1 & 114.01 & 81.30 & 0.71 & 3.90 & 4.78 & 2.39 & 2.55 & 6.54 & 2.00 & 1.88 & - \\
\hline 142x60x13-t1.3-N100-A0-FR-T2 & 113.58 & 81.30 & 0.72 & 3.90 & 4.81 & 2.39 & 2.55 & 6.54 & 2.01 & 1.89 & - \\
\hline 142x60x13-t1.3-N100-A0-FR-T3 & 113.77 & 81.30 & 0.71 & 3.90 & 4.76 & 2.39 & 2.55 & 6.54 & 1.99 & 1.87 & - \\
\hline 142x60x13-t1.3-N120-A0-FR & 111.67 & 96.00 & 0.86 & 3.84 & 5.41 & 2.72 & 2.99 & 7.24 & 1.99 & 1.81 & - \\
\hline 142x60x13-t1.3-N150-A0-FR & 112.64 & 120.97 & 1.07 & 3.87 & 5.56 & 2.99 & 3.42 & 7.78 & 1.86 & 1.62 & - \\
\hline 202x65x15-t1.4-N100-A0-FR & 147.62 & 74.07 & 0.50 & 3.70 & 3.43 & 2.69 & 2.81 & 8.67 & 1.27 & 1.22 & - \\
\hline 202x65x15-t1.4-N120-A0-FR & 147.68 & 88.89 & 0.60 & 3.70 & 4.60 & 2.92 & 3.16 & 9.29 & 1.58 & 1.46 & - \\
\hline 202x65x15-t1.4-N150-A0-FR & 147.72 & 111.11 & 0.75 & 3.70 & 4.96 & 3.26 & 3.67 & 10.13 & 1.52 & 1.35 & - \\
\hline $302 \times 90 \times 18-\mathrm{t} 2.0-\mathrm{N} 100-\mathrm{A} 0-\mathrm{FR}$ & 157.69 & 52.63 & 0.33 & 2.63 & 7.92 & 6.00 & 5.89 & 14.17 & 1.32 & 1.35 & 0.56 \\
\hline $302 \times 90 \times 18-\mathrm{t} 2.0-\mathrm{N} 120-\mathrm{A} 0-\mathrm{FR}$ & 157.13 & 63.16 & 0.40 & 2.63 & 8.66 & 6.42 & 6.52 & 15.15 & 1.35 & 1.33 & 0.57 \\
\hline 302x90x18-t2.0-N150-A0-FR & 157.67 & 78.95 & 0.50 & 2.63 & 8.81 & 7.03 & 7.44 & 16.45 & 1.25 & 1.18 & 0.54 \\
\hline Mean, $\mathrm{P}_{\mathrm{m}}$ & & & & & & & & & 1.65 & 1.54 & 0.56 \\
\hline Coefficient of variation, $V_{p}$ & & & & & & & & & 0.20 & 0.18 & 0.03 \\
\hline
\end{tabular}


Table 8

Comparison of experimental and numerical results with design strength for case of flanges fastened to bearing plates

\begin{tabular}{|c|c|c|c|c|c|c|c|c|c|c|c|}
\hline \multirow[t]{2}{*}{ Specimen } & \multirow{2}{*}{$\begin{array}{c}\text { Web } \\
\text { slenderness } \\
\text { h/t }\end{array}$} & \multirow{2}{*}{ 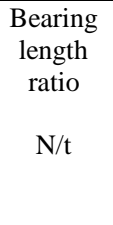 } & \multirow{2}{*}{$\begin{array}{c}\text { Bearing } \\
\text { length } \\
\text { ratio } \\
\mathrm{N} / \mathrm{h}\end{array}$} & \multirow{2}{*}{$\begin{array}{l}\text { Inside } \\
\text { bend } \\
\text { radius } \\
\text { ratio } \\
\text { ri/t }\end{array}$} & \multirow{2}{*}{$\begin{array}{c}\text { Failure } \\
\text { load per } \\
\text { web } \\
\left(\mathrm{P}_{\text {EXP }}\right) \\
\text { P } \\
(\mathrm{kN})\end{array}$} & \multicolumn{3}{|c|}{$\begin{array}{l}\text { Web crippling strength per } \\
\text { web predicted from current } \\
\text { design codes }\end{array}$} & \multicolumn{3}{|c|}{ Comparison } \\
\hline & & & & & & $\begin{array}{l}\mathrm{P}_{\mathrm{BS}} \\
(\mathrm{kN})\end{array}$ & $\begin{array}{l}\mathrm{P}_{\text {Euro. }} \\
(\mathrm{kN})\end{array}$ & $\begin{array}{l}\mathrm{P}_{\mathrm{NAS}} \\
(\mathrm{kN})\end{array}$ & $\mathrm{P} / \mathrm{P}_{\mathrm{BS}}$ & $\mathrm{P} / \mathrm{P}_{\text {Euro }}$ & $\mathrm{P} / \mathrm{P}_{\mathrm{NAS}}$ \\
\hline 142x60x13-t1.3-N100-A0-FX-T1 & 113.56 & 81.30 & 0.72 & 3.90 & 7.07 & 3.38 & 3.38 & 6.54 & 2.09 & 2.09 & - \\
\hline 142x60x13-t1.3-N100-A0-FX-T2 & 113.61 & 81.30 & 0.72 & 3.90 & 6.80 & 3.38 & 3.38 & 6.54 & 2.01 & 2.01 & - \\
\hline 142x60x13-t1.3-N100-A0-FX-T3 & 113.59 & 81.30 & 0.72 & 3.90 & 7.04 & 3.38 & 3.38 & 6.54 & 2.08 & 2.08 & - \\
\hline 142x60x13-t1.3-N120-A0-FX & 111.72 & 96.00 & 0.86 & 3.84 & 7.33 & 3.85 & 3.86 & 7.24 & 1.90 & 1.90 & - \\
\hline 142x60x13-t1.3-N150-A0-FX & 112.73 & 120.97 & 1.07 & 3.87 & 7.97 & 4.23 & 4.23 & 7.78 & 1.89 & 1.88 & - \\
\hline 202x65x15-t1.4-N100-A0-FX & 147.63 & 74.07 & 0.50 & 3.70 & 6.53 & 3.68 & 3.69 & 8.67 & 1.77 & 1.77 & - \\
\hline 202x65x15-t1.4-N120-A0-FX & 147.64 & 88.89 & 0.60 & 3.70 & 7.11 & 4.00 & 4.00 & 9.29 & 1.78 & 1.78 & - \\
\hline 202x65x15-t1.4-N150-A0-FX & 147.64 & 111.11 & 0.75 & 3.70 & 7.73 & 4.47 & 4.47 & 10.13 & 1.73 & 1.73 & - \\
\hline $302 \times 90 \times 18-t 2.0-\mathrm{N} 100-\mathrm{A} 0-\mathrm{FX}$ & 157.43 & 52.63 & 0.33 & 2.63 & 11.07 & 8.14 & 8.14 & 14.17 & 1.36 & 1.36 & 0.78 \\
\hline $302 \times 90 \times 18-t 2.0-\mathrm{N} 120-\mathrm{A} 0-\mathrm{FX}$ & 157.66 & 63.16 & 0.40 & 2.63 & 12.31 & 8.69 & 8.70 & 15.14 & 1.42 & 1.41 & 0.81 \\
\hline $302 \times 90 \times 18-t 2.0-\mathrm{N} 150-\mathrm{A} 0-\mathrm{FX}$ & 157.66 & 78.95 & 0.50 & 2.63 & 12.58 & 9.53 & 9.54 & 16.45 & 1.32 & 1.32 & 0.76 \\
\hline Mean, $\mathrm{P}_{\mathrm{m}}$ & & & & & & & & & 1.76 & 1.76 & 0.79 \\
\hline Coefficient of variation, $V_{p}$ & & & & & & & & & 0.16 & 0.16 & 0.03 \\
\hline
\end{tabular}


Table 9

Comparison of web crippling strength with NAS design strength for offset hole where flanges fastened to bearing plates

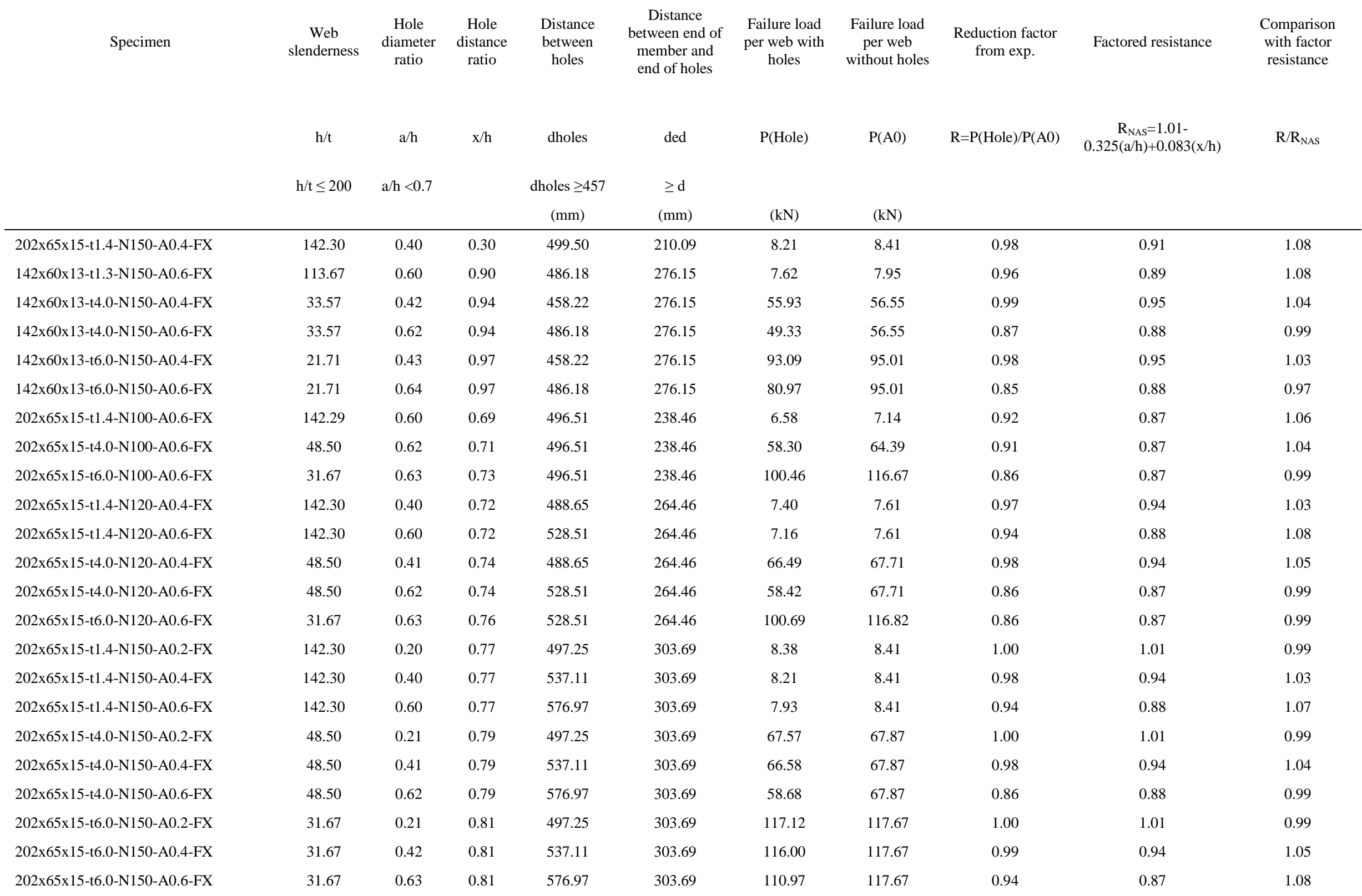




\begin{tabular}{|c|c|c|c|c|c|c|c|c|c|c|}
\hline $302 \times 90 \times 18-\mathrm{t} 2.0-\mathrm{N} 120-\mathrm{A} 0.2-\mathrm{FX}$ & 157.66 & 0.20 & 0.64 & 562.07 & 311.08 & 13.77 & 13.91 & 0.99 & 1.00 & 0.99 \\
\hline $302 \times 90 \times 18-\mathrm{t} 2.0-\mathrm{N} 120-\mathrm{A} 0.4-\mathrm{FX}$ & 157.66 & 0.40 & 0.64 & 621.98 & 311.08 & 13.53 & 13.91 & 0.97 & 0.93 & 1.04 \\
\hline $302 \times 90 \times 18-\mathrm{t} 4.0-\mathrm{N} 120-\mathrm{A} 0.2-\mathrm{FX}$ & 73.84 & 0.41 & 0.65 & 562.07 & 311.08 & 67.60 & 67.88 & 1.00 & 0.93 & 1.07 \\
\hline 302x90x18-t4.0-N120-A0.4-FX & 73.84 & 0.41 & 0.65 & 621.98 & 311.08 & 66.91 & 67.88 & 0.99 & 0.93 & 1.06 \\
\hline $302 \times 90 \times 18-\mathrm{t} 6.0-\mathrm{N} 120-\mathrm{A} 0.2-\mathrm{FX}$ & 48.56 & 0.41 & 0.66 & 562.07 & 311.08 & 153.58 & 155.93 & 0.98 & 0.93 & 1.06 \\
\hline 302x90x18-t6.0-N120-A0.4-FX & 48.56 & 0.41 & 0.66 & 621.98 & 311.08 & 144.15 & 155.93 & 0.92 & 0.93 & 0.99 \\
\hline $302 \times 90 \times 18-\mathrm{t} 2.0-\mathrm{N} 150-\mathrm{A} 0.2-\mathrm{FX}$ & 157.66 & 0.20 & 0.67 & 609.30 & 349.69 & 15.34 & 15.43 & 0.99 & 1.00 & 0.99 \\
\hline $302 \times 90 \times 18-\mathrm{t} 2.0-\mathrm{N} 150-\mathrm{A} 0.4-\mathrm{FX}$ & 157.66 & 0.40 & 0.67 & 669.21 & 349.69 & 15.11 & 15.43 & 0.98 & 0.94 & 1.05 \\
\hline $302 \times 90 \times 18-44.0-\mathrm{N} 150-\mathrm{A} 0.2-\mathrm{FX}$ & 73.84 & 0.20 & 0.68 & 609.30 & 349.69 & 74.13 & 74.35 & 1.00 & 1.00 & 1.00 \\
\hline 302x90x18-t4.0-N150-A0.4-FX & 73.84 & 0.41 & 0.68 & 669.21 & 349.69 & 73.54 & 74.35 & 0.99 & 0.93 & 1.06 \\
\hline $302 \times 90 \times 18-\mathrm{t} 6.0-\mathrm{N} 150-\mathrm{A} 0.2-\mathrm{FX}$ & 48.56 & 0.21 & 0.69 & 609.30 & 349.69 & 156.38 & 156.97 & 1.00 & 1.00 & 1.00 \\
\hline 302x90x18-t6.0-N150-A0.4-FX & 48.56 & 0.41 & 0.69 & 669.21 & 349.69 & 154.46 & 156.97 & 0.98 & 0.93 & 1.05 \\
\hline 202x65x15-t1.4-N150-A0.4-X0.6-FX & 142.30 & 0.40 & 0.60 & 468.90 & 269.59 & 8.15 & 8.41 & 0.97 & 0.93 & 1.04 \\
\hline $202 \times 65 \times 15-\mathrm{t} 1.4-\mathrm{N} 150-\mathrm{A} 0.6-\mathrm{X} 0.6-\mathrm{FX}$ & 142.30 & 0.60 & 0.60 & 508.76 & 269.59 & 7.75 & 8.41 & 0.92 & 0.86 & 1.06 \\
\hline $302 \times 90 \times 18-\mathrm{t} 2.0-\mathrm{N} 150-\mathrm{A} 0.2-\mathrm{X} 0.6-\mathrm{FX}$ & 157.66 & 0.20 & 0.60 & 569.38 & 329.73 & 15.41 & 15.43 & 1.00 & 0.99 & 1.00 \\
\hline $302 \times 90 \times 18-\mathrm{t} 2.0-\mathrm{N} 150-\mathrm{A} 0.4 \mathrm{X}-0.6-\mathrm{FX}$ & 157.66 & 0.40 & 0.60 & 629.29 & 329.73 & 15.01 & 15.43 & 0.97 & 0.93 & 1.05 \\
\hline Mean & & & & & & & & & & 1.03 \\
\hline $\mathrm{COV}$ & & & & & & & & & & 0.03 \\
\hline
\end{tabular}


Table 10

Statistical analysis for comparison of strength reduction factor for centred hole where flanges unfastened to bearing plates

\begin{tabular}{ll}
\hline Statistical parameters & $R($ Test \& FEA $) / R p(0.96-0.34(a / h)+0.09(N / h))$ \\
\hline Number of data & 91 \\
Mean, $P_{\mathrm{m}}$ & 1.00 \\
Coefficient of variation, $V_{\mathrm{p}}$ & 0.09 \\
Reliability index, $\beta$ & 2.69 \\
Resistance factor, $\phi$ & 0.85 \\
\hline
\end{tabular}

Table 11

Statistical analysis for comparison of strength reduction factor for centred hole where flanges fastened to bearing plates

Statistical parameters $R$ (Test \& FEA) / $R p(0.93-0.41(a / h)+0.16(N / h))$

Number of data 91

Mean, $P_{\mathrm{m}}$

Coefficient of variation, $V_{\mathrm{p}}$

Reliability index, $\beta$

2.69

Resistance factor, $\phi$

0.85 
Table 12

Statistical analysis for comparison of strength reduction factor for offset hole where flanges unfastened to bearing plates Statistical parameters $R$ (Test \& FEA) / $R p(0.97-0.26(a / h)+0.14(x / h))$

$\begin{array}{ll}\text { Number of data } & 228 \\ \text { Mean, } P_{\mathrm{m}} & 1.00 \\ \text { Coefficient of variation, } V_{\mathrm{p}} & 0.04 \\ \text { Reliability index, } \beta & 2.86 \\ \text { Resistance factor, } \phi & 0.85\end{array}$

Table 13

Statistical analysis for comparison of strength reduction factor for offset hole where flanges fastened to bearing plates Statistical parameters $R$ (Test \& FEA) / $R p(0.97-0.14(a / h)+0.07(x / h))$

Number of data 228

Mean, $P_{\mathrm{m}}$

Coefficient of variation, $V_{\mathrm{p}}$

Reliability index, $\beta$

0.03

Resistance factor, $\phi$

2.91

0.85 


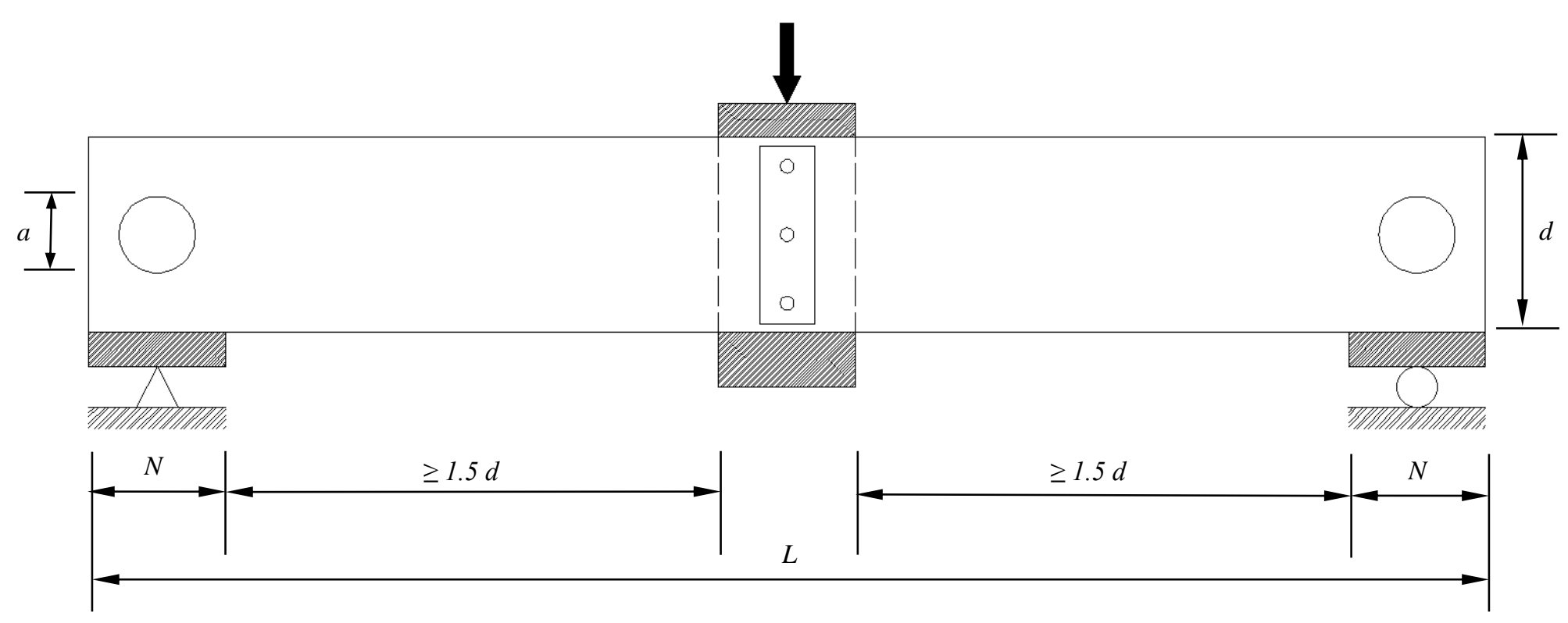

(a) With holes centred above bearing plate 


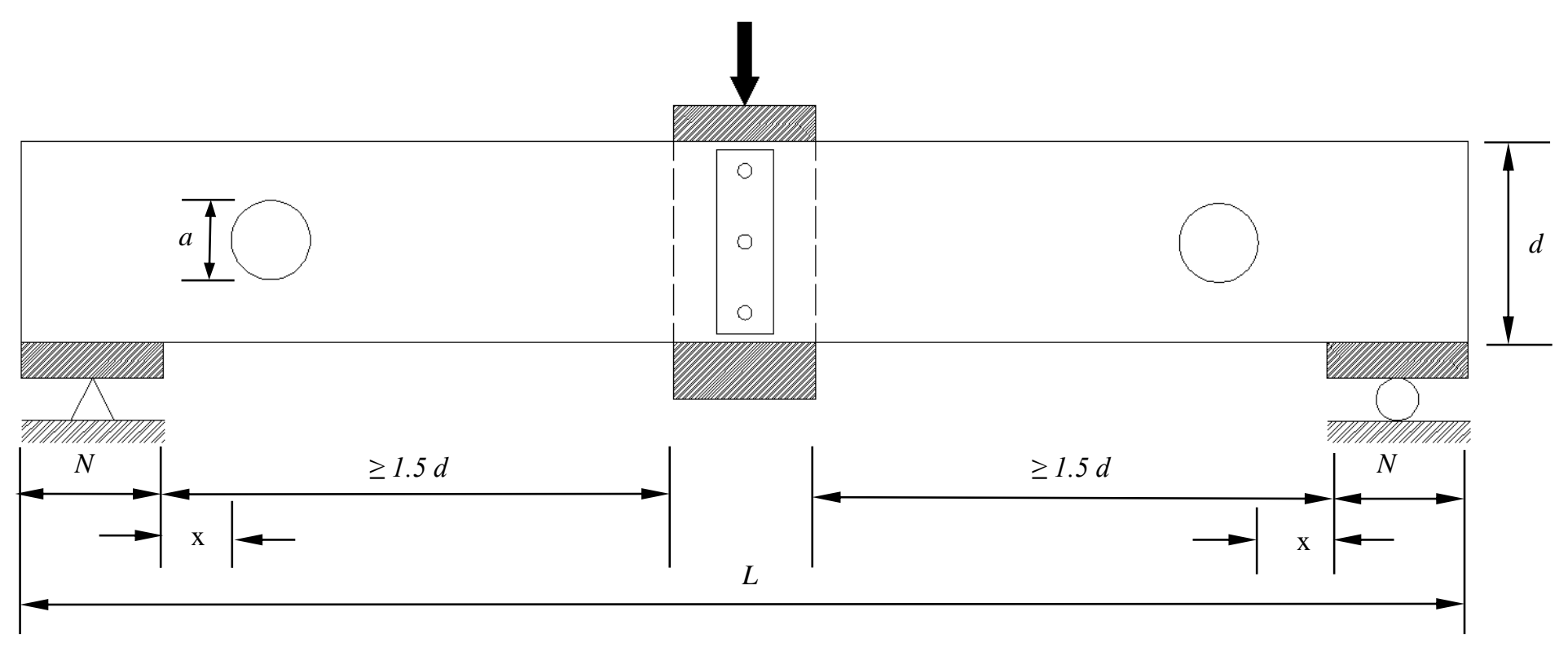

(b) With holes offset from bearing plate

Fig.1 End-one-flange loading condition 


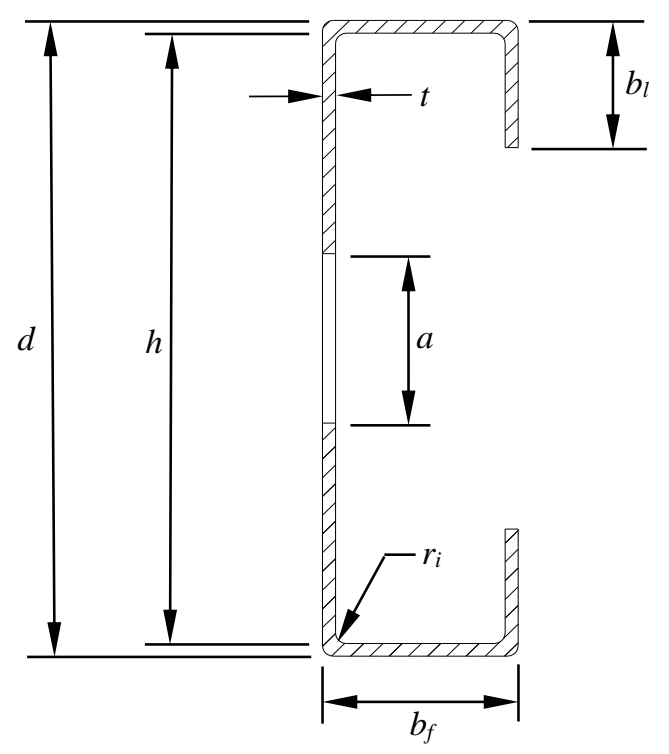

Fig.2 Definition of symbols 


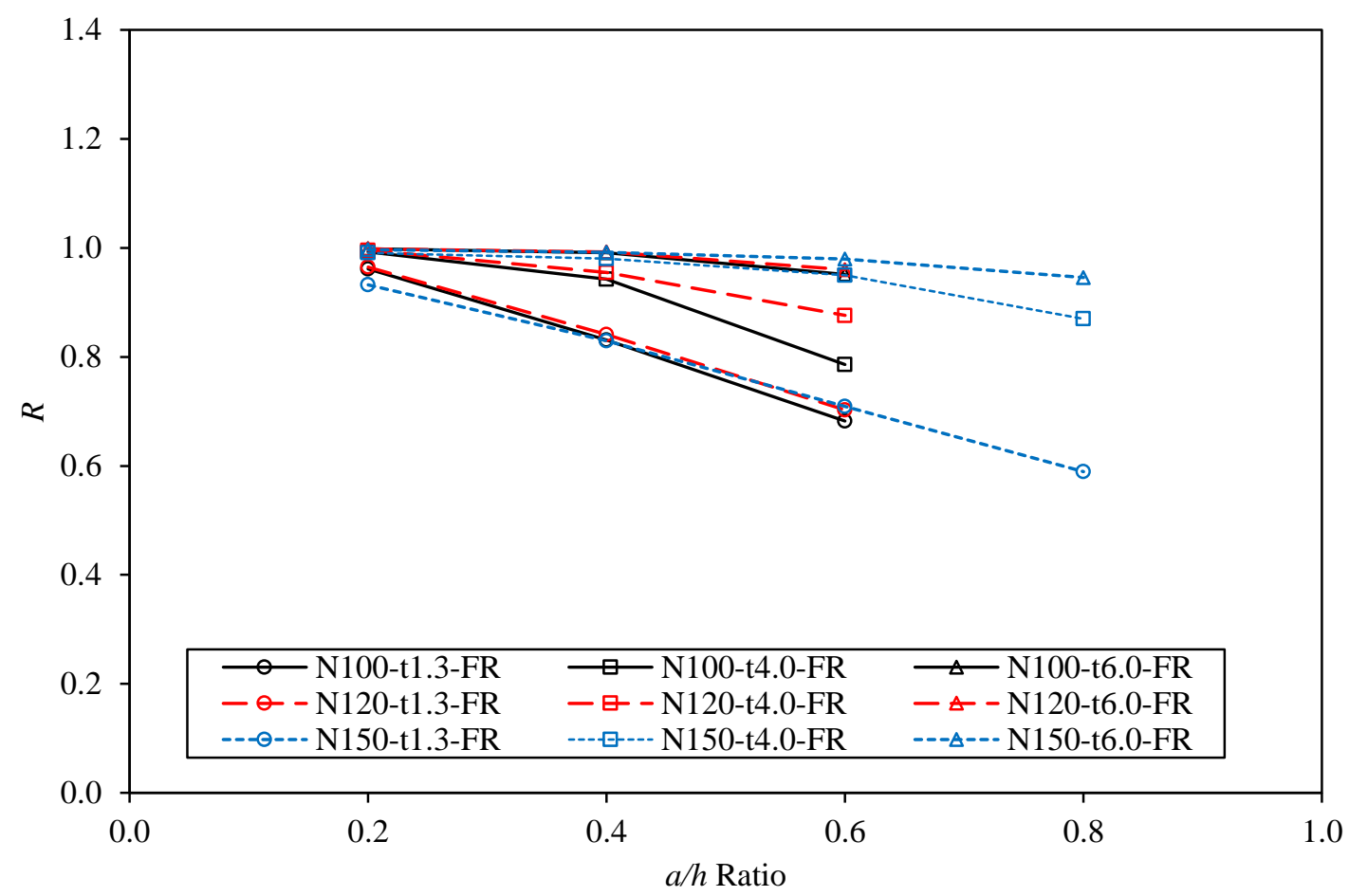

(a) Flanges unfastened case

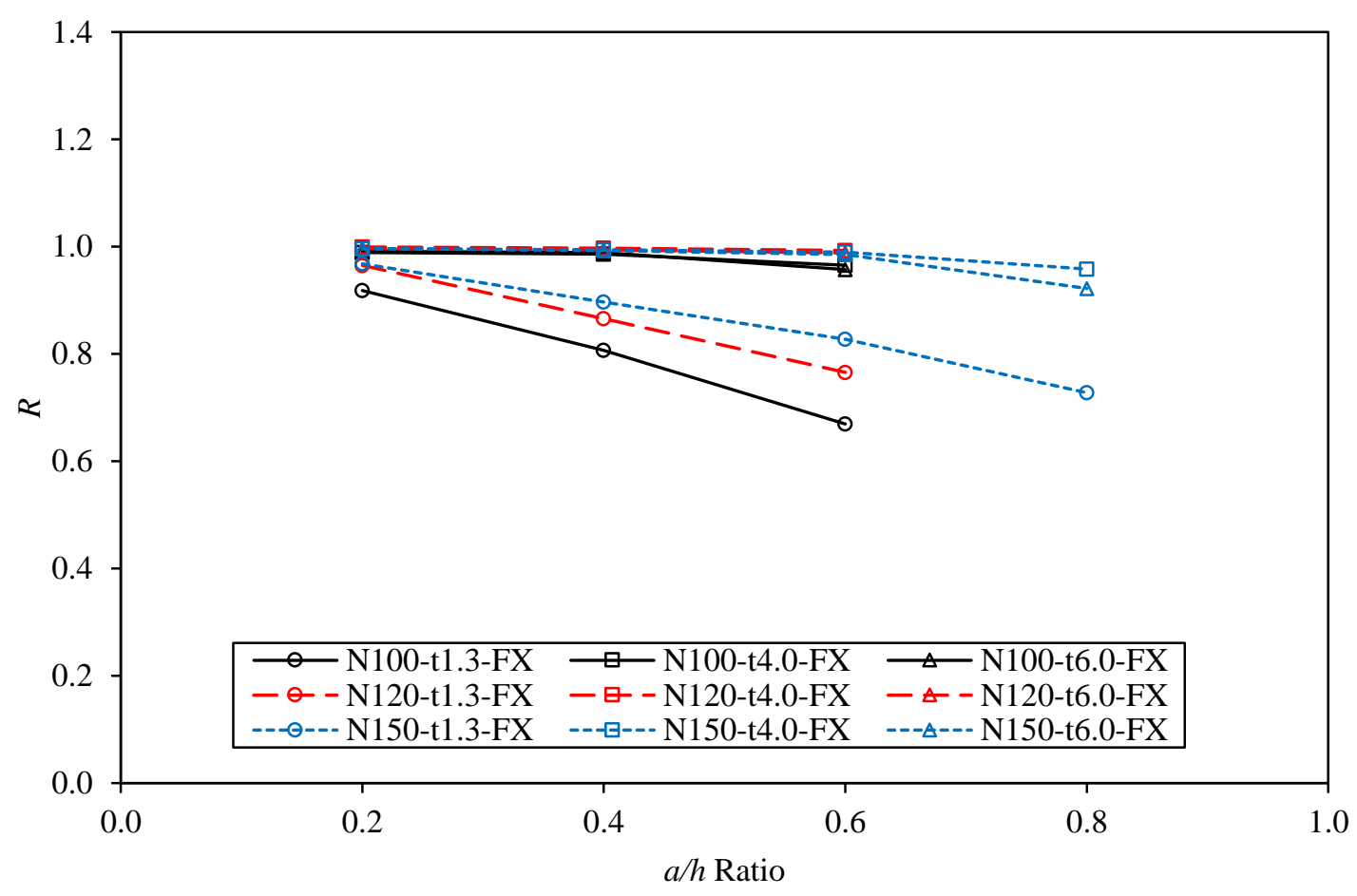

(b) Flanges fastened case

Fig.3 Variation in reduction factors with $a / h$ for $\mathrm{C} 142$ section with centred hole 


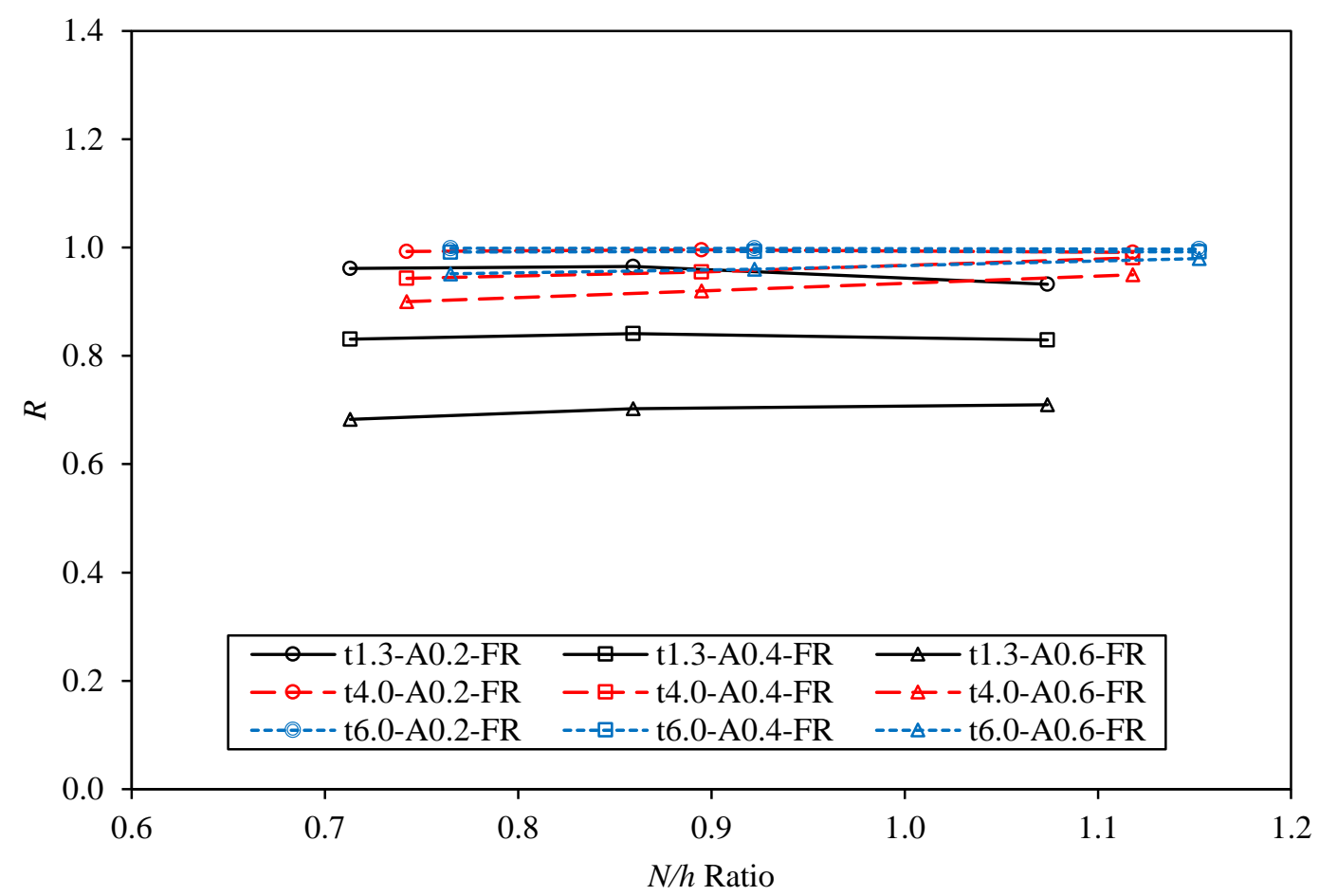

(a) Flanges unfastened case

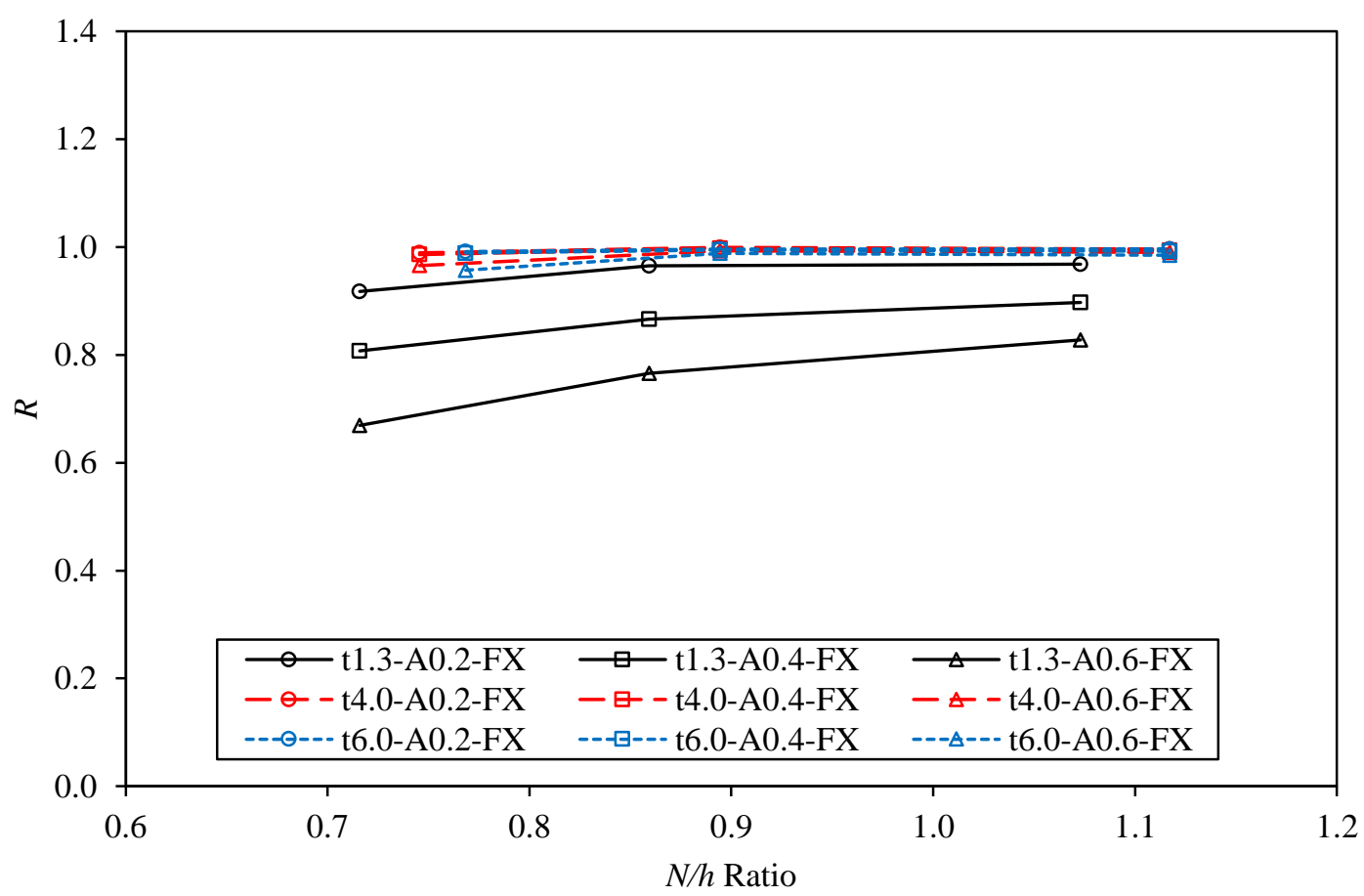

(b) Flanges fastened case

Fig.4 Variation in reduction factors with $N / h$ for $\mathrm{C} 142$ section with centred hole 


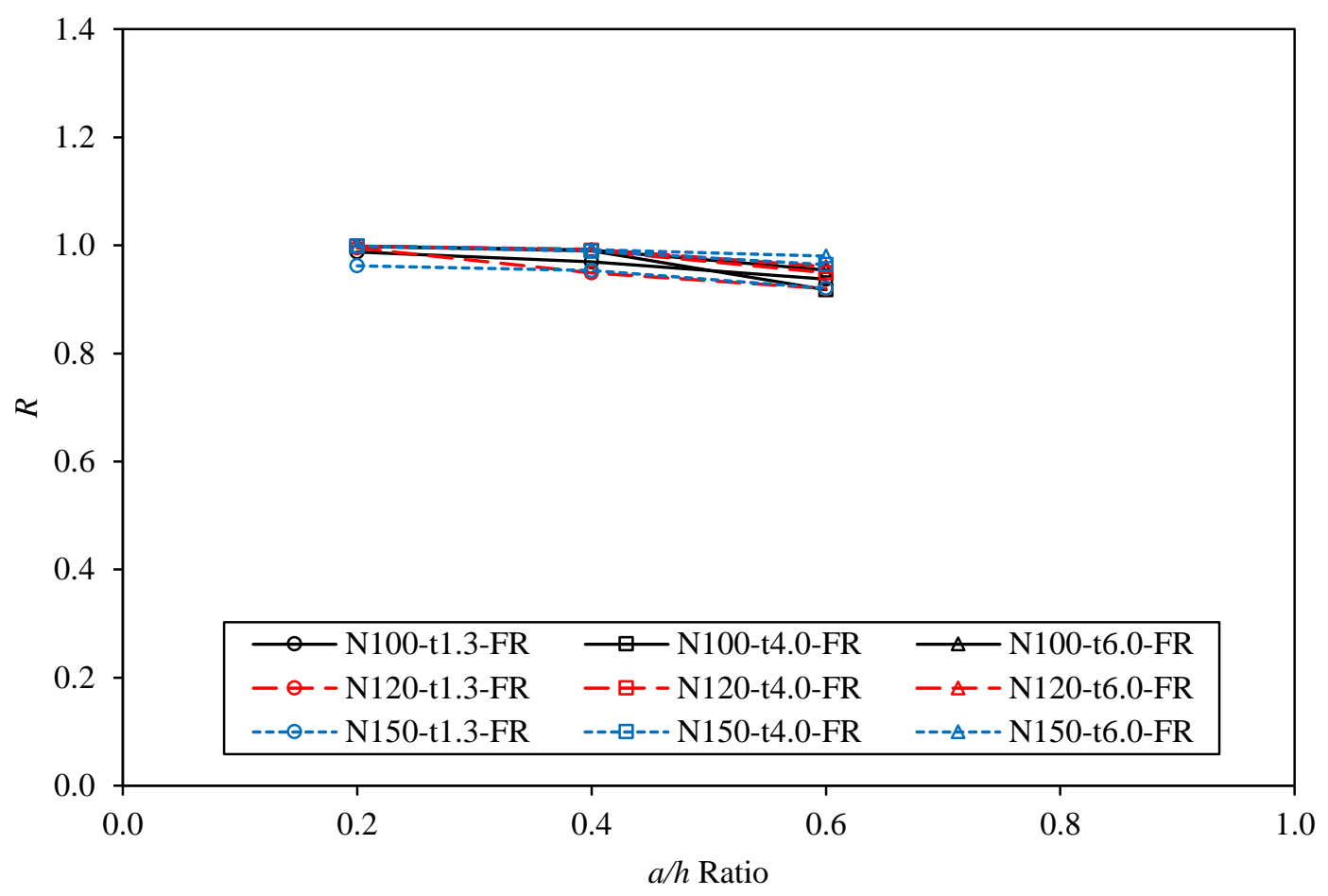

(a) Flanges unfastened case

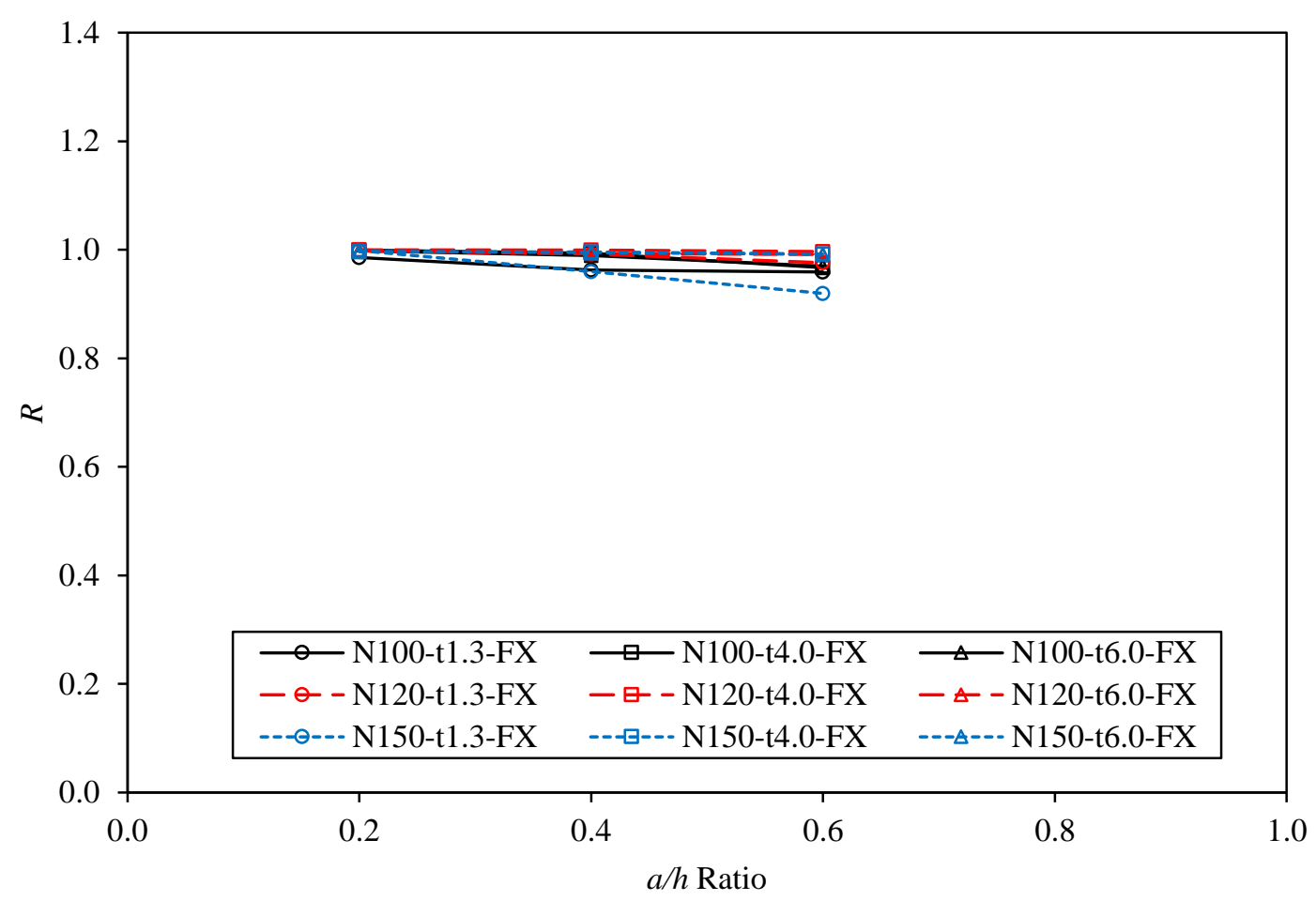

(b) Flanges fastened case

Fig.5 Variation in reduction factors with $a / h$ for $\mathrm{C} 142$ section with offset hole 


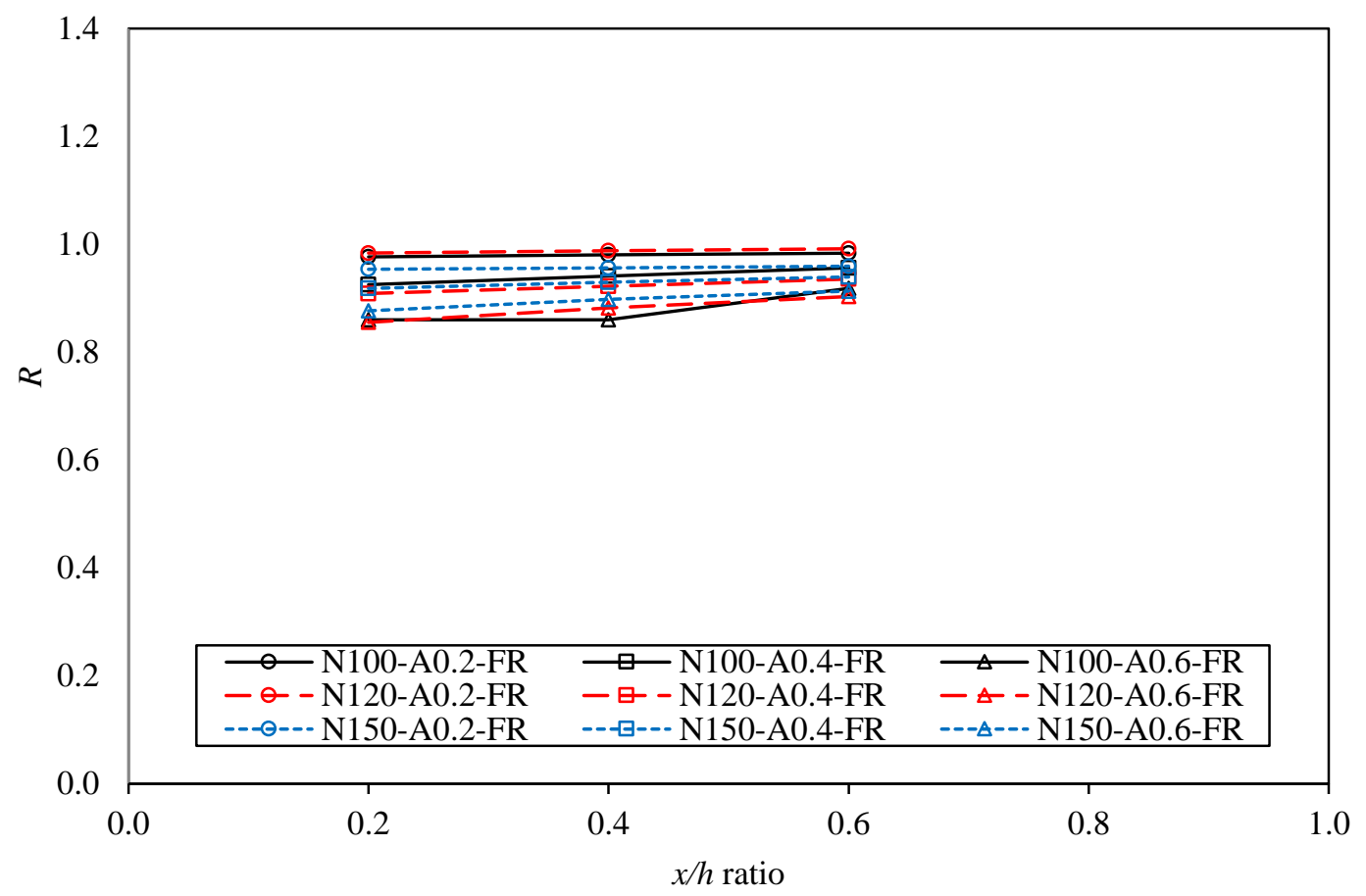

(a) Flanges unfastened case

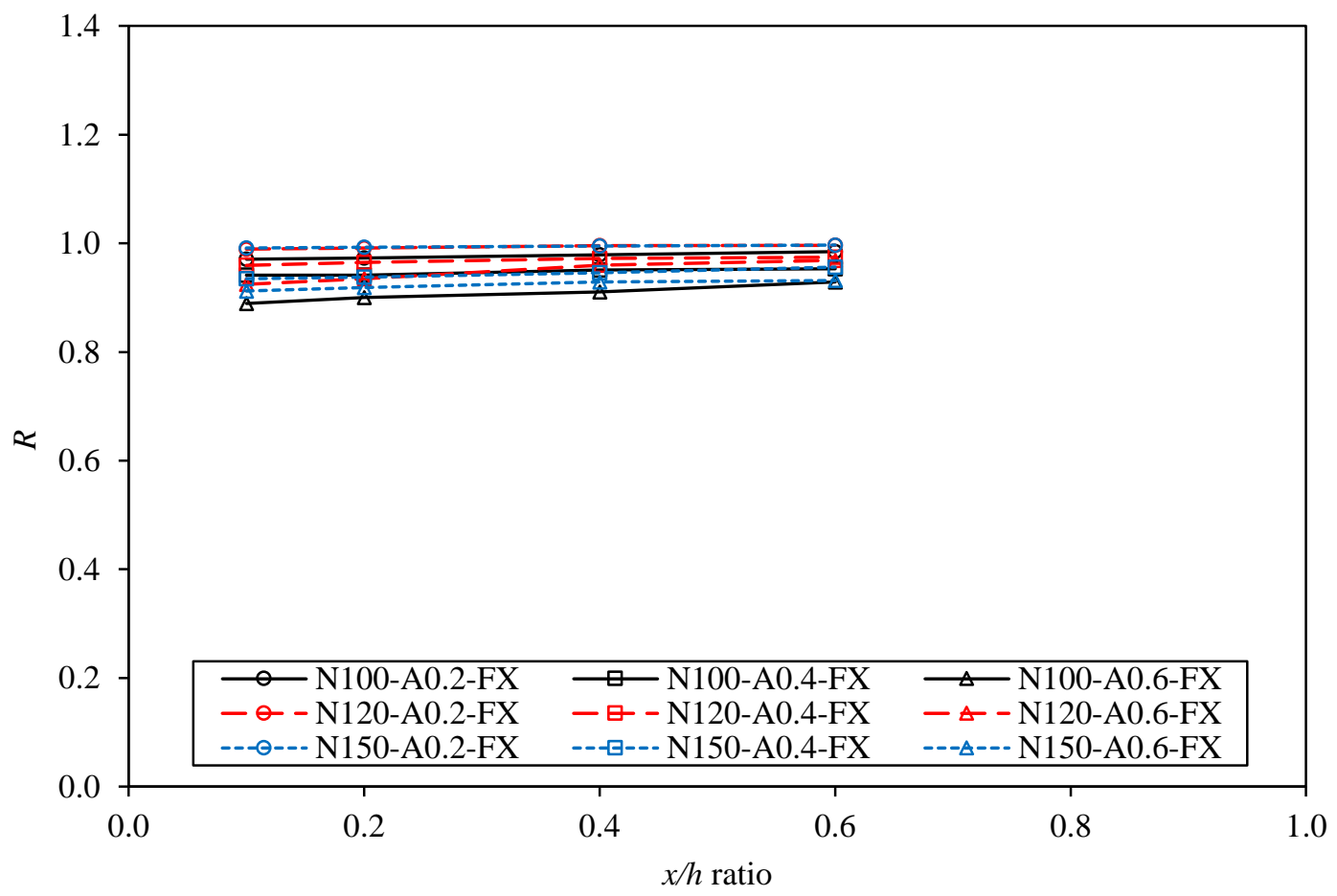

(b) Flanges fastened case

Fig.6 Variation in reduction factors with $x / h$ for $\mathrm{C} 142$ section with offset hole 

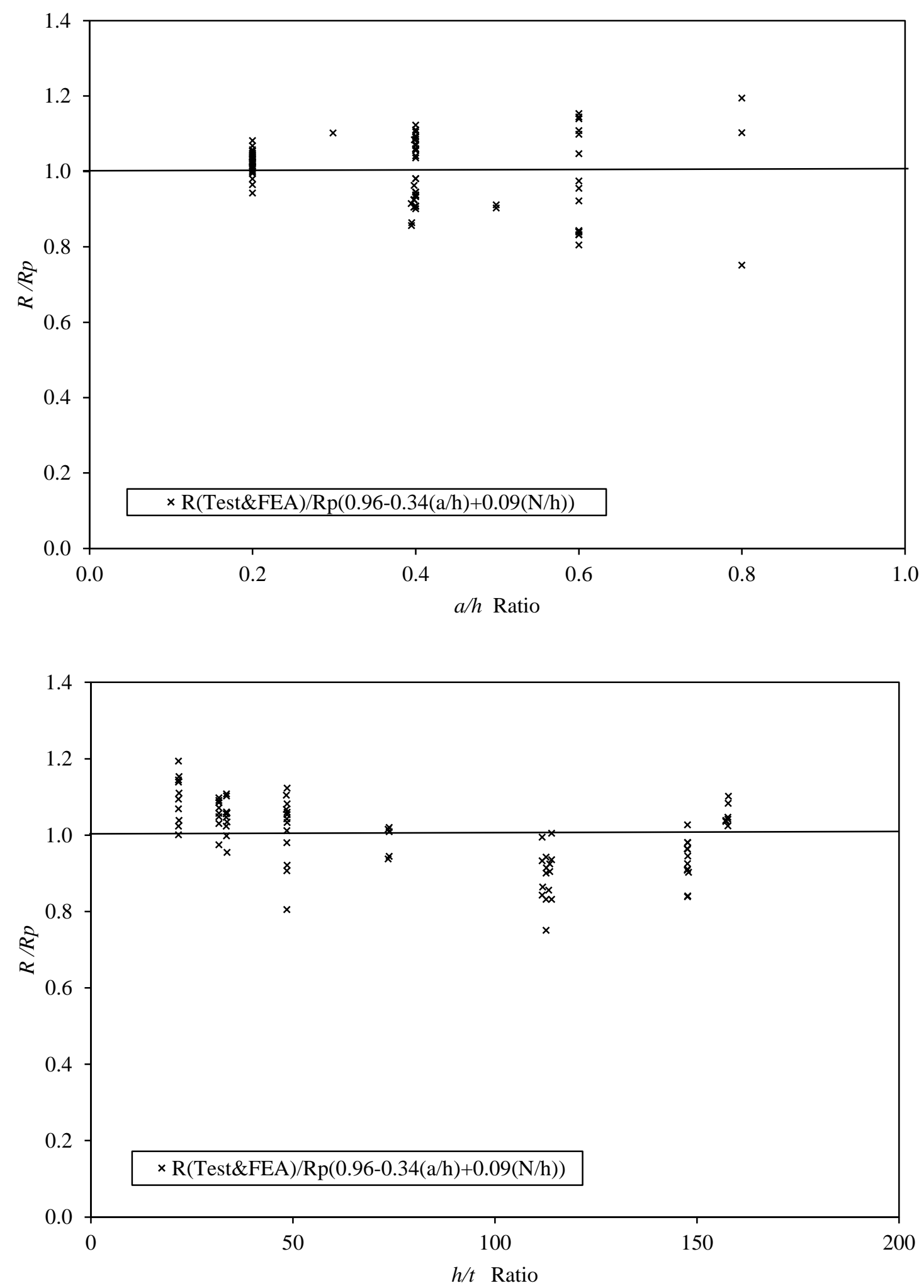

Fig.7 Comparison of strength reduction factor for centred hole where flanges unfastened to bearing plates 

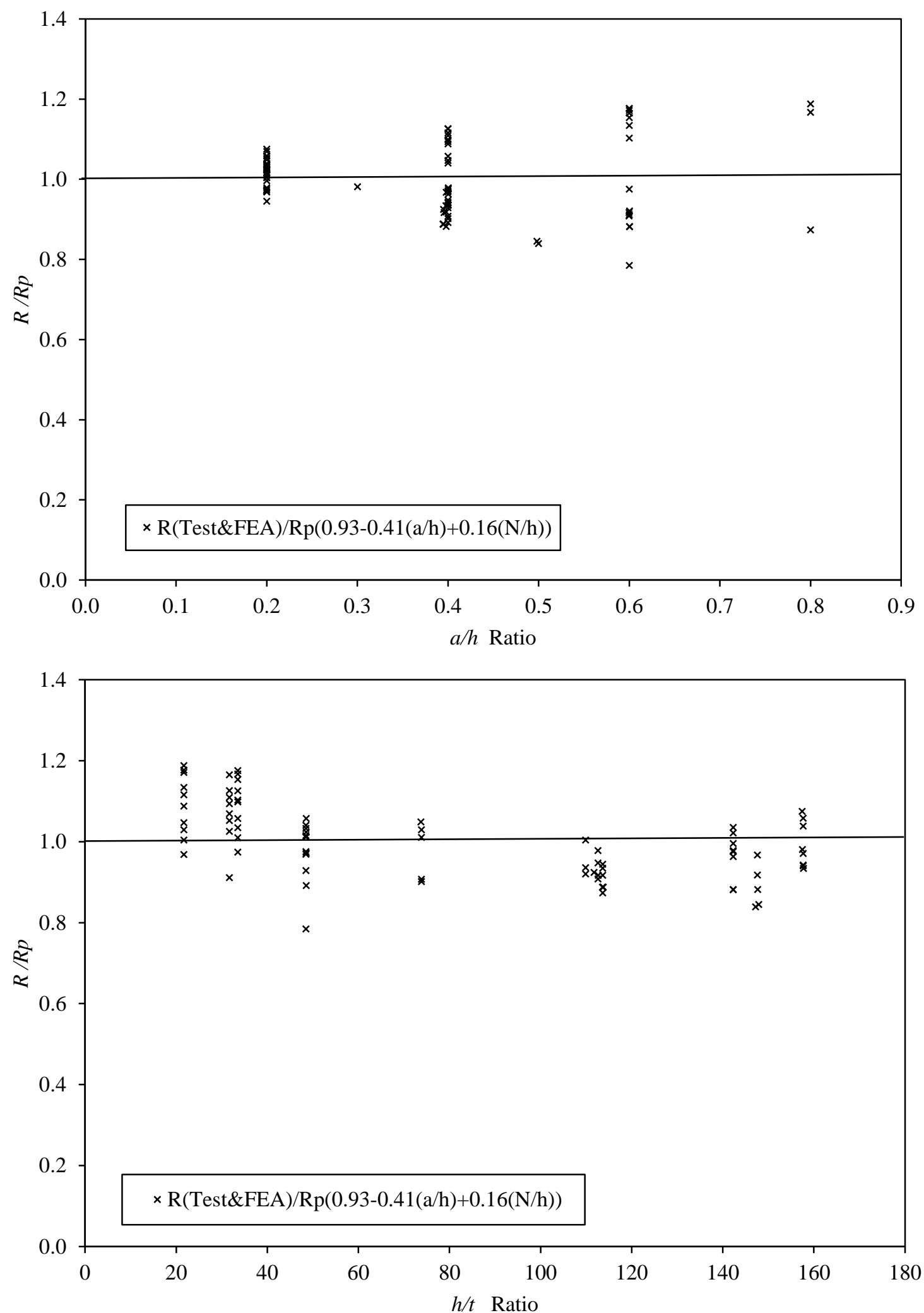

Fig.8 Comparison of strength reduction factor for centred hole where flanges fastened to bearing plates 

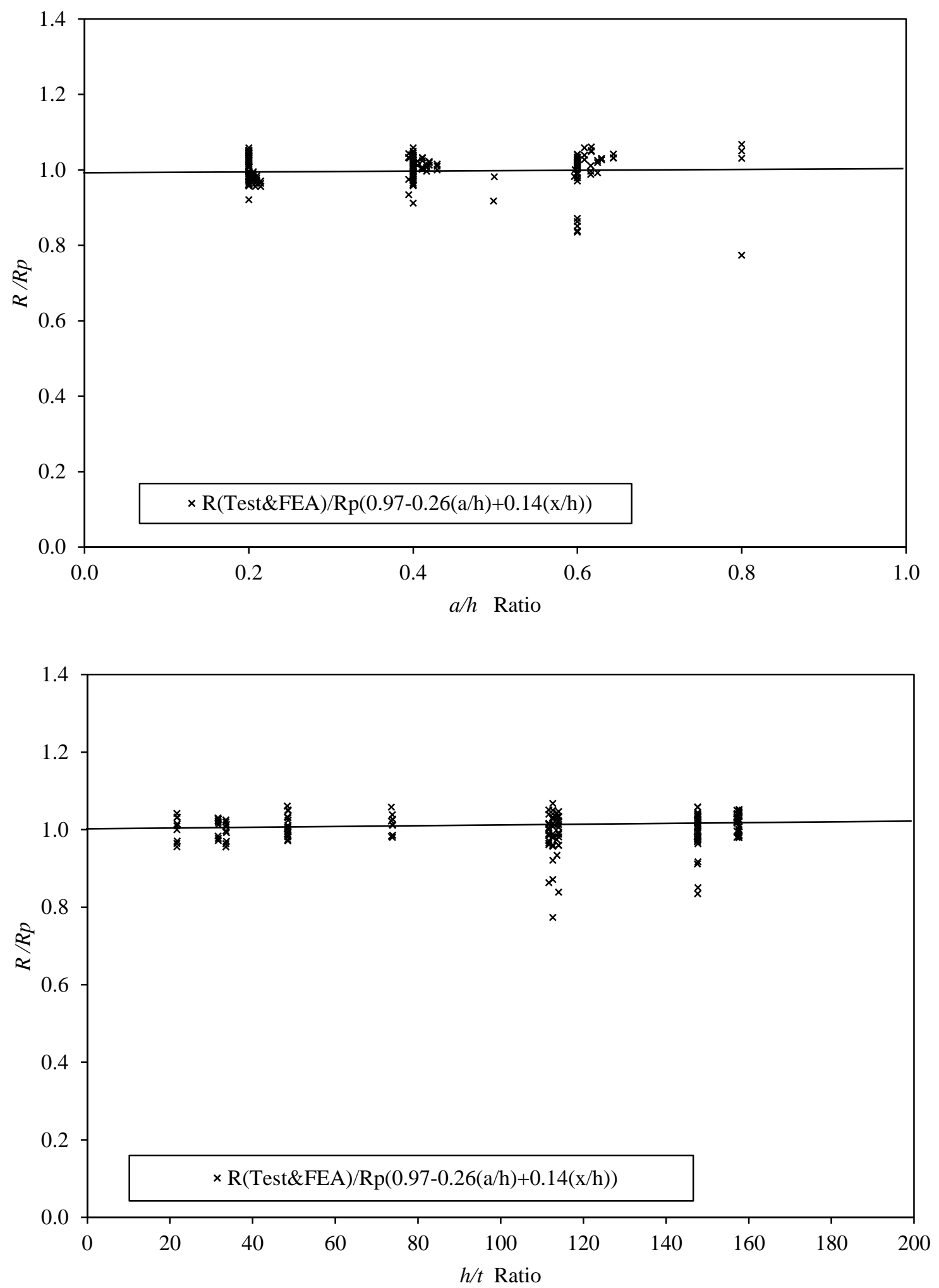

Fig.9 Comparison of strength reduction factor for offset hole where flanges unfastened to bearing plates 

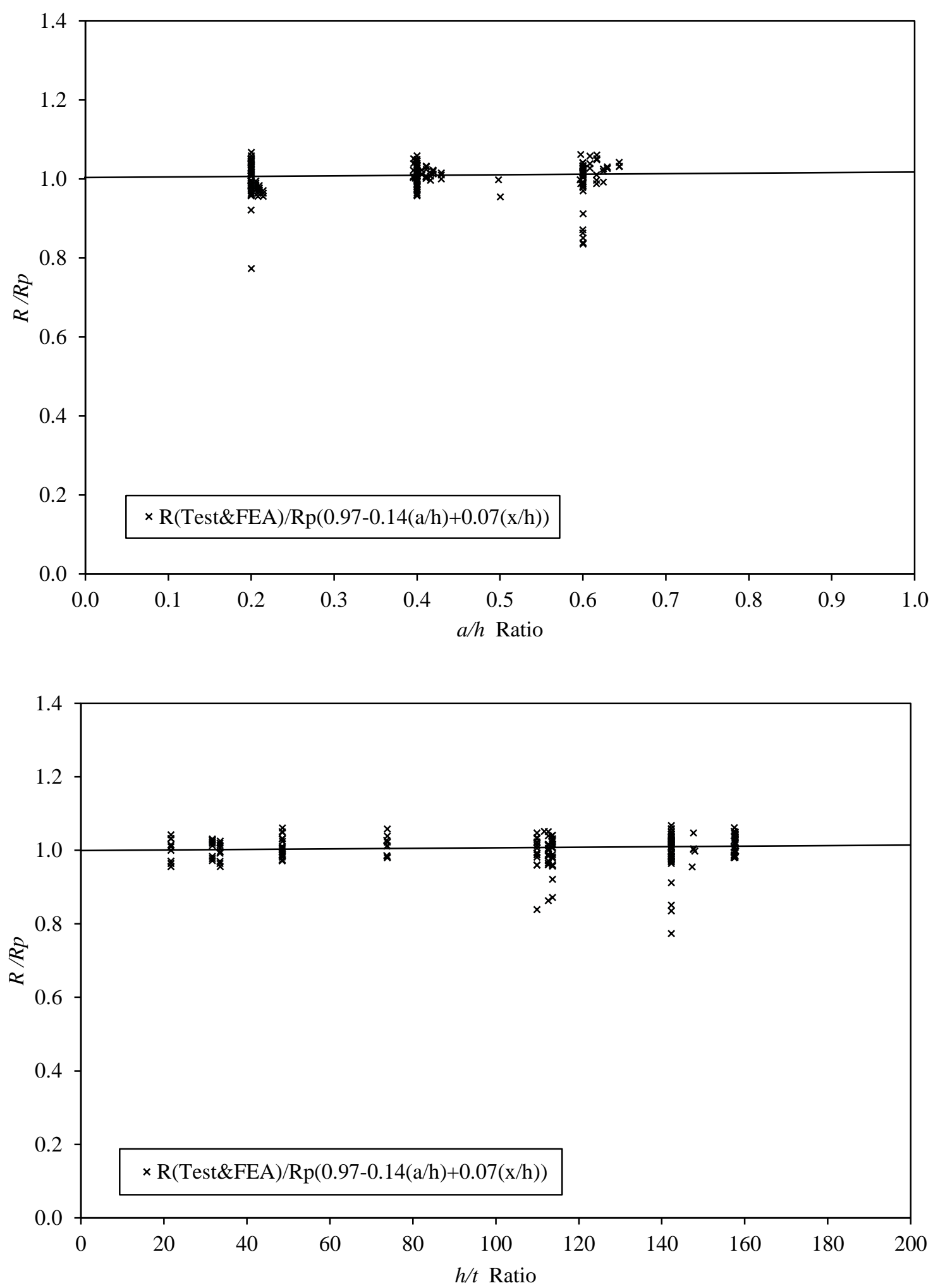

Fig.10 Comparison of strength reduction factor for offset hole where flanges fastened to bearing plates 